ISSN: 0213-2060

DOI: https://doi.org/10.14201/shhme2020382239262

\title{
LA FUNDACIÓN Y LAS PRIMERAS DÉCADAS DEL MONASTERIO DE FRESDELVAL. MEMORIA, BENEFACTORÍA Y DEVOCIÓN JERÓNIMA EN LA CASTILLA BAJOMEDIEVAL ${ }^{1}$
}

\author{
The Foundation and the First Decades of the Monastery of Fresdelval. Memory, \\ Benefactoria and Hieronymite Devotion in Late Medieval Castile
}

Juan A. PRIETO SAYAGUÉS

Depto. de Historia de América y Medieval y Ciencias Historiográficas. Facultad de Geografía e Historia. Universidad Complutense de Madrid. Calle del Prof. Aranguren, s/n. E-28040 MADRID. C. e.: juananpr@ucm.es

\section{Diana LUCÍA GÓMEZ-CHACÓN}

Depto. de Historia del Arte. Facultad de Geografia e Historia. Universidad Complutense de Madrid. Calle del Prof. Aranguren,s/n.E-28040 MADRID. C. e.: dianaluc@ucm.es

Recibido: 2020-01-26

Revisado: 2020-07-25

Aceptado: 2020-10-26

RESUMEN: Se expone la fundación del monasterio jerónimo de Fresdelval por el adelantado mayor de Castilla, Gómez Manrique, y su esposa, Sancha de Rojas, y la benefactoría ejercida hacia el cenobio por los miembros de sus linajes, sus criados y oficiales, vecinos de Burgos y de otras localidades cercanas. Dicha benefactoría continuó más allá de sus decesos con la elección de sus enterramientos y la dotación de oficios perpetuos en el monasterio, destacando el majestuoso sepulcro del matrimonio fundador, objeto de análisis. A cambio del patronato de los fundadores y de las donaciones de los bienhechores, el monasterio y su comunidad ofrecieron una serie de servicios socioeconómicos a los mismos. Nobleza.

Palabras clave: Jerónimos; Sepulcro; Siglo xv; Patronato y benefactoría; Monasterio;

1 Este trabajo se enmarca en los Proyectos de Investigación «Expresiones de la cultura política peninsular en las relaciones de conflicto (Corona de Castilla, 1230-1504)", ref. HAR2016-76174-P, del Programa Estatal de Fomento de la Investigación Científica y Técnica de Excelencia, y «El ejercicio del poder: espacios, agentes y escrituras (siglos XI-Xv)", ref. HAR2017-84718-P, financiado por el MINECO/AEI/FEDER (UE). 

BENEFACTORÍA Y DEVOCIÓN JERÓNIMA EN LA CASTILLA BAJOMEDIEVAL JUAN A. PRIETO SAYAGUÉS Y DIANA LUCÍA GÓMEZ-CHACÓN

ABSTRACT: This paper analyses the foundation of the Hieronymite monastery of Fresdelval by the Adelantado of Castile, Gómez Manrique, and his wife Sancha de Rojas, and the benefactoria exercised towards the monastery by the members of their lineages, their servants and officers, neighbours of Burgos and other nearby towns. This practice of benefactoria continued beyond their deaths with the choice of burials and the endowment of perpetual offices, highlighting the majestic tomb of the founders, subject to analysis. In exchange for the patronage of the founders and the donations of the well-doers, the monastery and its community offered them a number of socio-economic services.

Keywords: Hieronymites; Sepulchre; $15^{\text {th }}$ Century; Patronage and benefactoría; Monastery; Nobility.

SUMARIO: 0 Introducción. 1 Aparición mariana, reconstrucción de la ermita, y fundación y construcción del monasterio. 2 El sepulcro de Gómez Manrique y Sancha de Rojas. 3 Otros espacios funerarios y enterramientos. 4 Las donaciones y dotaciones de oficios de los fundadores y bienhechores. 5 Conclusiones. 6 Fuentes inéditas. 7 Referencias bibliográficas.

\section{INTRODUCCIÓN}

En el presente trabajo nos proponemos revisar la documentación conservada sobre el monasterio bajo el patronato de Gómez Manrique, la benefactoría y oficios litúrgicos dotados por los miembros de su familia y de otros personajes, destacar su valor históricoartístico y examinar las obras realizadas durante la primera mitad del siglo xv, así como los inicios del proceso constructivo del conjunto y la propuesta de autoría del sepulcro de los fundadores, retomando los trabajos de Gómez Bárcena.

\section{ApARICIÓN MARIANA, RECONSTRUCCIÓN DE LA ERMiTA, Y FUNDACIÓN Y CONSTRUCCIÓN DEL MONASTERIO}

El monasterio fue fundado en 1404 sobre una ermita en la que se rendía culto desde tiempos de Recaredo a una imagen de la Virgen, redescubierta en época de Alfonso XI. Dos resurrecciones tuvieron como consecuencia la contribución a las obras del monasterio y la donación de trigo para la fábrica de la capilla y una casulla por parte de varios bienhechores de la zona ${ }^{2}$.

A finales del siglo xIv, el VI señor de Amusco y adelantado mayor de Castilla, Pero Manrique, mandó reconstruir la ermita, que se encontraba dentro de sus posesiones.

2 Carrero Santamaría, Eduardo. «La Virgen del adelantado mayor de Castilla don Gómez Manrique, originaria del monasterio jerónimo de Nuestra Señora de Fresdelval». Archivo Español de Arte, 1994, n. ${ }^{\circ}$ 265, p. 79; Balaguer, Víctor. En Burgos. Recuerdos de esta ciudad insigne. Madrid: El Progreso Editorial, 1895, pp. 111-112 y 116; Gil, Isidro. Memorias históricas de Burgos y su provincia. Burgos: Imprenta de Segundo Fournier, 1913, p. 187; SigüenZA, José de. Historia de la Orden de San Jerónimo. Valladolid: Junta de Castilla y León, 2000, tomo I, pp. 189-190. 
LA FUNDACIÓN Y LAS PRIMERAS DÉCADAS DEL MONASTERIO DE FRESDELVAL. MEMORIA, BENEFACTORÍA Y DEVOCIÓN JERÓNIMA EN LA CASTILLA BAJOMEDIEVAL

JUAN A. PRIETO SAYAGUÉS Y DIANA LUCÍA GÓMEZ-CHACÓN

El adelantado «tomó a su cargo ser patrón y defensor de la ermita». Al igual que otros monasterios con advocación mariana fundados en fechas próximas, como Guadalupe o Santa María la Real de Nieva, Fresdelval se convirtió en un santuario de peregrinación. En su testamento, el bachiller en leyes y vecino de Burgos, Francisco Martínez, mandó a sus albaceas que enviasen a dos hombres para hacer vigilia por él, uno a Guadalupe y otro a Fresdelval, y que ordenasen decir dos misas cantadas por su alma en cada monasterio $(21 / \mathrm{X} / 1422)^{3}$.

En 1400, el nuevo adelantado mayor de Castilla, Gómez Manrique, y su mujer, Sancha de Rojas, mandaron construir un palacio junto a la ermita. La Virgen obró dos milagros a favor de su familia: gracias al primero de ellos su hija mayor, María, recuperó el habla cuando tenía siete u ocho años y, tres años más tarde, intercedió para que Gómez Manrique saliese ileso de la batalla de Antequera. El adelantado guardó el pasavolante y lo colgó delante del altar de la Virgen ${ }^{4}$.

En su viaje de regreso a Castilla Gómez Manrique visitó Guadalupe. Movido por la protección ofrecida por la familia real al santuario, decidió entregar la ermita de Fresdelval a la Orden de San Jerónimo. Carrero expuso que una de sus principales motivaciones fue su condición de bastardo y advenedizo en la corte, llevándole a fundar un panteón familiar, escogiendo para ello una orden nueva que comenzaba a captar la atención nobiliaria y que mantenía una estrecha relación con la monarquía, cuyo favor ansiaba el adelantado. A ello hay que sumar el hecho de que Gómez Manrique era oficial de la corte y que la orden había sido fundada por varios miembros pertenecientes a este grupo, como ejemplifica la familia Pecha y el resto de bienhechores con los que contaron los monasterios jerónimos durante la Baja Edad Media. El deseo del adelantado de vincular Fresdelval y Guadalupe queda de manifiesto en su testamento (21/IV/1410), en el que ordenó que fuese prior del primero el vicario de Guadalupe, quien se encontraba en

3 El primer capellán fue Ruiz González de Villayerno, sucedido por García Fernández; en BaLAGUER, En Burgos, pp. 113-114; Castro, Manuel de. El Real Monasterio de Santa Clara de Palencia y los Enríquez, Almirantes de Castilla. Palencia: Diputación Provincial de Palencia, 1982, p. 106; Sigüenza, Historia, pp. 190-191; Salazar y Castro, Luis. Historia genealógica de la Casa de Lara. Madrid: Imprenta Real, 1696, tomo I, pp. 418-419; Cañas Gálvez, Francisco de P. El itinerario de la corte de Juan II de Castilla (14181454). Madrid: Sílex, 2007, p. 131; AHN, Clero, Pergaminos, C. 218, n. ${ }^{\circ} 17$.

4 Sigüenza, Historia, pp. 191-192; CaÑas Gálvez, Francisco de P. «Devoción mariana y poder regio: las visitas reales al monasterio de Guadalupe durante los siglos XIV y XV (ca. 1330-1472)». Hispania Sacra,

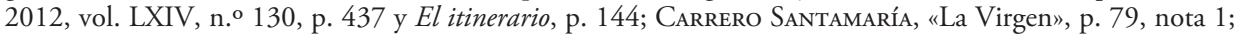
Martínez Díez, Gonzalo. Nacimiento y muerte de un monasterio burgalés. Santa María de Fresdelval. Burgos: Imprenta de la Diputación, 1996, pp. 9-10; Rodríguez-Picavea Matilla, Enrique. «Nobleza y sociedad en la Castilla bajomedieval. El linaje Padilla en los siglos XIV-XV». Studia Historica. Historia Medieval, 2015, vol. 33, pp. 141 y 146; Lora Serrano, Gloria. «La fundación del monasterio de San Vicente de Plasencia. La tumba del poder». En Córdoba de la Llave, Ricardo; Pino García, José Luis del y Cabrera Sánchez, Margarita (coords.). Estudios en homenaje al profesor Emilio Cabrera. Córdoba: Universidad de Córdoba, 2015, p. 315; Montero Tejada, Rosa M. ${ }^{a}$. Nobleza y sociedad en Castilla. El linaje Manrique (siglos XIV-XVI). Madrid: Caja Madrid, 1996, p. 339; Yarza LuACEs, Joaquín. La nobleza ante el rey. Los grandes linajes castellanos y el arte en el siglo XV. Madrid: El Viso, 2003, p. 126; Beceiro Pita, Isabel. "La nobleza y las órdenes mendicantes en Castilla (1350-1530)». En Beceiro Pita, Isabel (coord.). Poder, piedad y devoción. Castilla y su entorno. Siglos XII-XV. Madrid: Sílex, 2014, p. 329. 
LA FUNDACIÓN Y LAS PRIMERAS DÉCADAS DEL MONASTERIO DE FRESDELVAL. MEMORIA, BENEFACTORÍA Y DEVOCIÓN JERÓNIMA EN LA CASTILLA BAJOMEDIEVAL JUAN A. PRIETO SAYAGUÉS Y DIANA LUCÍA GÓMEZ-CHACÓN

Fresdelval, y rogó al capellán, Garci Fernández, que tomase el hábito, estableciendo una comunidad de entre quince y veinte religiosos 5 .

El prior de Guadalupe, Fernando Yánez, envió a tres religiosos para la nueva fundación: un prior, un vicario y un procurador. La Memoria de los bienhechores deste monesterio de nuestra Señora de Fres del Val fecha la colocación de la primera piedra el día de la Anunciación (25/III/1404). Benedicto XIII envió al abad de San Millán de Lara y al provisor de Burgos para que comprobasen si se daban las condiciones para la entrada de una comunidad en Fresdelval (29/I/1409). En 1410, a petición del adelantado, se agregó la ermita al monasterio con licencia del obispo de Burgos ${ }^{6}$.

Pese a que Sigüenza afirma que la ermita no llegó a incorporarse al monasterio, parece que sí lo fue. De hecho, como demostró Carrero, esta conformaría el núcleo inicial de la iglesia monástica. En su testamento, Gómez Manrique se refiere al templo de la siguiente manera: la dicha iglesia quando era hermita. El documento de una permuta de propiedades entre el adelantado y el cabildo de Burgos para ensanchar la ermita (12/ III/1405) nos informa de que el noble tenía comenzada una capilla e iglesia de cal y canto, muy grande y hermosa, y que quería ensanchar más la iglesia y ermita, pero no se podía hacer sin tomar parte de las tierras del cabildo, lo que fecharía el inicio de las obras de ampliación del templo en 1405. El adelantado, con licencia de los vicarios generales, entregó las tierras y heredades de la misma al cabildo, a cambio de las que necesitaba para ampliar la obra ${ }^{7}$.

El templo, de nave única con capillas laterales a manera de transepto, fue ampliado por su lado oriental, dando como resultado un nuevo presbiterio, de considerables dimensiones, cubierto por una bóveda octopartita, y proyectado como lugar de enterramiento de Gómez Manrique y su esposa. Según lo señalado por Ruiz Hernando, el gran impulso experimentado por los jerónimos en el siglo Xv vino acompañado de numerosas fundaciones, cuyas iglesias presentaban, generalmente, nave única y cabecera poligonal,

5 Montero Tejada, Nobleza, p. 339; Ruiz Hernando, José Antonio. Los monasterios jerónimos españoles. Segovia: Caja Segovia, 1997, p. 66; CASTro, El Real Monasterio, p. 106; Salazar y Castro, Historia genealógica, 1696, p. 21; LADERo QuesadA, Miguel Á. «Mecenazgo real y nobiliario en monasterios españoles: los jerónimos (siglos xv y xvi)». Principe de Viana. Homenaje a José María Lacarra, 1986, Anejo 3-vol. XLVII, p. 419; Serrano Fatigati, Enrique. «Manriques y Padillas. Brevísima historia de Fresdelval». La Ilustración Española y Americana, 1894, vol. XXX, p. 91; Yarza Luaces, La nobleza, p. 177; Carrero SanTAMARÍA, Eduardo. «Ntra. Sra. de Fresdelval y sus nobles fundadores. Una fábrica monástica condicionada a su patronazgo». En Campos y Fernández de Sevilla, Francisco J. (coord.). La Orden de San Jerónimo y sus monasterios. Actas del Simposium (I). San Lorenzo del Escorial: Ediciones Escurialenses, 1999, p. 296; PrIETo SAYAGUÉs, Juan A. «La orden jerónima: un siglo de servicio y bajo la protección de la monarquía y los oficiales de la corte Trastámara (1373-1474)». En Cañas Gálvez, Francisco de P. y Nieto Soria, José M. (coords.). Casa y Corte. Ámbitos de poder en los reinos hispánicos durante la Baja Edad Media (1230-1516). Madrid: La Ergástula, 2019, pp. 97-122; AHN, Clero, Legajo 1.053.

6 AHN, Clero, L. 18.978, fol. 38r; Serrano Fatigati, «Manriques y Padillas», p. 91; Gómez BárCeNA, M. ${ }^{a}$ Jesús. «El sepulcro de Gómez Manrique y Sancha de Rojas. Conservado en el Museo Arqueológico de Burgos». Reales Sitios. Revista del Patrimonio Nacional, 1985, vol. 83, p. 30; SIGÜEnzA, Historia, p. 192; Ruiz De Loizaga, Saturnino. Documentación medieval de la diócesis de Burgos en el Archivo Vaticano (siglos XIV y XV). Roma: el autor, 2003, n. ${ }^{\circ}$ 19; SALAZAR y CASTro, Historia genealógica, 1696, p. 419; AHN, Clero, Legajo 1.053, doc. 7; AHN, Clero, Libro 18.978.

AHN, Clero, Legajo 1.053, doc. 7; Carrero Santamaría, «Ntra. Sra. de Fresdelval», p. 298; AHN, Clero, Pergaminos, carp. 217, n. ${ }^{\circ} 13$. 
LA FUNDACIÓN Y LAS PRIMERAS DÉCADAS DEL MONASTERIO DE FRESDELVAL. MEMORIA, BENEFACTORÍA Y DEVOCIÓN JERÓNIMA EN LA CASTILLA BAJOMEDIEVAL

JUAN A. PRIETO SAYAGUÉS Y DIANA LUCÍA GÓMEZ-CHACÓN

más raramente cuadrada, siendo este último el caso de Fresdelval. Carrero destacó la anómala planimetría de la iglesia, en la que llaman la atención las dos capillas abiertas a ambos lados del tercer tramo, que no solo habrían funcionado en un primer momento como transepto, sino que condicionarían la posterior construcción del claustro. La ampliación del templo implicaría la ruptura del muro oriental y la construcción del tramo de crucero, el transepto y la nueva cabecera, con fines funerarios. Los muros habrían sido sobreelevados, buscando la homogeneización de la altura de todos ellos y el posterior abovedamiento del conjunto. Por su parte, los brazos del primitivo transepto se convirtieron en espacios funerarios de miembros de la familia Manrique ${ }^{8}$.

En su testamento, el adelantado insiste en la necesidad de facer la claustra -cuya construcción, quizás, se hubiese ya iniciado, aunque de manera muy primaria-, el dormitorio e refetorio, y acabar el dicho monesterio. Además, al inicio del documento, ordenó enterrar su cuerpo en la capilla mayor del monesterio que yo fago de Santa Maria de Fresdelval e que me entierren en la sepultura de alabastro que ay tengo fecha delante el altar mayor, lo que indica que la parte correspondiente a la ampliación de la ermita estaba prácticamente concluida, justificando tanto el encargo y financiación por parte del noble de unas puertas ricas y buenas, otra más pequeña que comunicaba la iglesia con el claustro, cerrojos o cerraduras con sus llaves para las puertas, la sillería del coro bien rico e bien fermosos de arbol e con oro, ubicado entre la capilla mediana e la mayor. Además, ordenó dar al monasterio todo el azul de acre que tenía Juan Martínez Calabaza y paños de oro, si los tuviese el anterior o Gonzalo Gómez, para pintar la obra de la iglesia. Lo anterior confirma que en 1410 las obras de ampliación del templo estaban concluidas o en un estado muy avanzado. Por lo tanto, podríamos fechar las obras de ampliación de la primitiva ermita, y su transformación en iglesia, entre 1405 y 1410/1411 (Figuras 1 y 2) ${ }^{9}$.

En su testamento, Gómez Manrique encargó al prior y al capellán que llevasen a buen término las obras y, en caso de no hacerlo, dio poder a su esposa para que les pudiera acusar y apremiar. También nos facilita el nombre de uno de los maestros que intervinieron en las obras, el maestre Brahen, morisco, a quien solicitó que se asegurase de que el dinero destinado para la obra se emplease en esta y que, en caso contrario, se lo notificase a su mujer, dato que, aparentemente, le presenta al mando de las obras. Le entregó 2.000 maravedís por sus servicios y pidió a su mujer y a sus herederos que le mantengan e fagan bien ${ }^{10}$.

8 Carrero Santamaría, «Ntra. Sra. de Fresdelval», pp. 296 y 298-300; Serrano Fatigati, Enrique. «Monasterio de Fresdelval. Galerías bajas del claustro procesional, ventanas del templo». Boletín de la Sociedad Española de Excursiones, 1902, vol. 117, p. 218; Ruiz Hernando, Los monasterios, p. 76.

9 El abovedamiento de los últimos tramos de la iglesia se concluyó a finales del siglo xv. De estas bóvedas solo se conservan in situ algunos fragmentos de las ménsulas sobre las que apoyaban los nervios del tramo de los pies, decoradas con ángeles tenantes de escudos, semiocultos tras los soportes del coro alto del siglo Xvi, en Carrero Santamaría, «Ntra. Sra. de Fresdelval», p. 315; AHN, Clero, Legajo 1.053, doc. 7.

10 En el apeo de propiedades urbanas capitulares reunidas en cuarenta y ocho demarcaciones o barrios de Burgos, realizado en 1404, se documentan, en la morería, hasta tres maestres Brahen -Brahen de los Escudos, Brahen de Toro y Brahen de los Lasos-, en AHN, Clero, Legajo 1.053, doc. 7; Araus Ballesteros, Luis y Villanueva Zubizarreta, Olatz. "Espacios, identidades y relaciones de los musulmanes de la ciudad de Burgos durante su minoría mudéjar». En Echevarría Arsuaga, Ana y FÁbregas García, Adela (coords.). De la alquería a la aljama. Madrid: UNED, 2016, nota 398. 

BENEFACTORÍA Y DEVOCIÓN JERÓNIMA EN LA CASTILLA BAJOMEDIEVAL JUAN A. PRIETO SAYAGUÉS Y DIANA LUCÍA GÓMEZ-CHACÓN

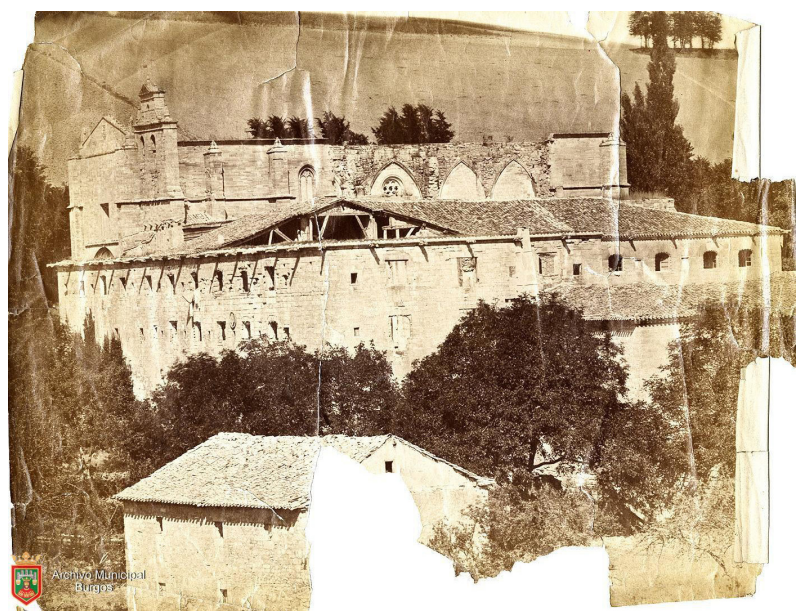

Figura 1. Vista del Monasterio de Nuestra Señora de Fresdelval en ruinas. Archivo General del Ayuntamiento de Burgos, Colección Gráfica, FC-4115.

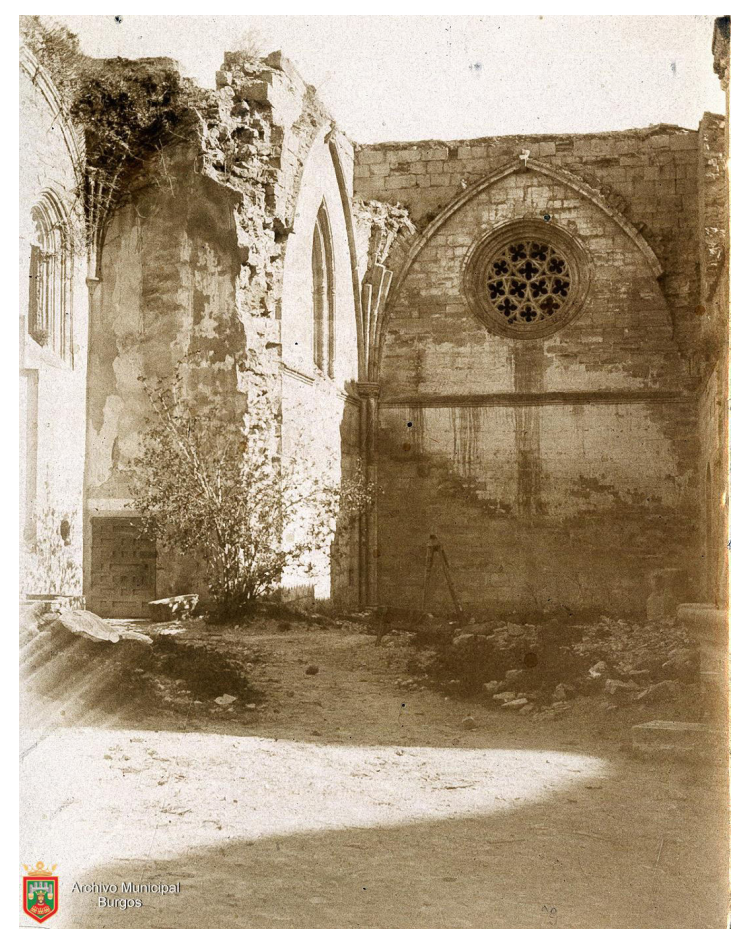

Figura 2. Vista parcial de las ruinas de la iglesia del Monasterio de Nuestra Señora de Fresdelval. Archivo General del Ayuntamiento de Burgos, Colección Gráfica, FC-3586. 
LA FUNDACIÓN Y LAS PRIMERAS DÉCADAS DEL MONASTERIO DE FRESDELVAL. MEMORIA, BENEFACTORÍA Y DEVOCIÓN JERÓNIMA EN LA CASTILLA BAJOMEDIEVAL

JUAN A. PRIETO SAYAGUÉS Y DIANA LUCÍA GÓMEZ-CHACÓN

Tres meses después de morir el adelantado, su viuda, encontrándose en el monasterio, ratificó todas las donaciones de su marido y otorgó una escritura de obligación por la que se comprometía a edificar en cuatro ańos el claustro, refectorio, dormitorios, un cabildo y cocina, bajo pena de 1.000 maravedís diarios por cada día que superase el plazo acordado (17/IX/1411). En el caso de no ser suficiente la donación de su marido, Sancha de Rojas se ofreció a correr con los gastos. En una rectificación de su testamento redactado el 4 de agosto de 1437 mandó 5.000 maravedís de juro situados en Frómista $(1 / \mathrm{IX} / 1437)^{11}$.

Según la Memoria de los bienhechores, el matrimonio edificó la yglesia y la claustra y parte del capitulo y todas las moradas que estaban encima de la claustra y refectorio, siendo el resto levantado por la comunidad con limosnas de los fieles. Según Sigüenza, el claustro se construyó a la par que se ampliaba el templo, hipótesis recogida en la Memoria de los bienhechores, en la que se indica que fue levantado en vida de Gómez Manrique. Sin embargo, como se ha señalado anteriormente, la sala capitular y la cocina fueron financiados por la viuda y concluidas en 1415 . Además, sabemos que hacia 1432 no se habían finalizado las obras de las dependencias monásticas. De hecho, en 1440, una de sus hijas, María, hizo entrega al monasterio de 150.000 maravedís para hacer el retablo del altar mayor, la enfermería, la cocina y una hospedería junto a la puerta de la iglesia, que derribaron posteriormente para hacer el paño de la pared de las $c^{2} l a s^{12}$.

11 AHN, Clero, L. 18.978, ff. 38v y 39r; AHN, Clero, Legajo 1053, doc. 3; GonzÁlez De Fauve,

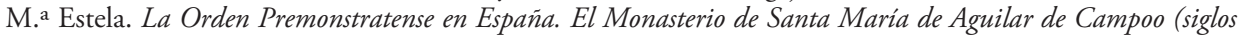
XI-XV). Tomo I: Texto. Aguilar de Campoo: Centro de Estudios del Románico, 1991, p. 276; López Mata, Teófilo. La ciudad y castillo de Burgos. Burgos: Ayuntamiento de Burgos, 1920, p. 85; Carrero Santamaría, «Ntra. Sra. de Fresdelval», p. 303; AHN, Clero, Pergaminos, carp. 218, no. 1 y 10; Revuelta Somalo, Josemaría. Los jerónimos. Guadalajara: Institución Provincial de Cultura Marqués de Santillana, 1982, p. 274.

12 Gómez Manrique donó 15.000 maravedís de juro para edificar el claustro y para que rogasen por su alma y la de sus familiares; 300 ovejas parideras y 150 corderos para la obra del claustro, 12 yeguas con 6 crianzas; 25.000 maravedís o hasta 30.000 que tomó de Fresdelval cuando era ermita, para la obra, ordenando que se los diesen de los que tenía Juan Martínez Calabaza del adelantado, o de 25.000 de juro que quedaban de la renta que compró al camarero del rey de Francia para hacer el claustro, dormitorio y refectorio; 2.000 florines de oro para acabar el cenobio; las carretas, bueyes, bestias y herramientas que estaban en el monasterio; 3.000 fanegas de pan del que Ruy Sánchez de Velasco tenía del testador para la obra de las tres dependencias susodichas y para que rogasen por su alma y la de sus familiares. Reiteró que la donación no la invirtiesen en nada que no fuera hacer el refectorio y dormitorio. Ordenó que, si su esposa no se casase e mantobiere castidad, toda su plata quedase para ella durante su vida sin poderla enajenar, salvo necesidad para casar a alguna de sus hijas y, después de fallecer, que quedase para la obra del monasterio y las moradas que tuviesen que hacer; en caso de que tuviese que venderla mandó que resarciesen al monasterio con el mismo importe, heredades o de otra manera. Entregó para las puertas ricas y buenas 3.000 maravedís y, si no fueran suficientes, 100 fanegas de pan; y para la que comunicaba la iglesia y el claustro 1.000 maravedís y 50 fanegas de pan; para los cerrojos y llaves destinó 1.000 maravedís; y para la sillería del coro 2.000 y 100 fanegas de pan; si costasen más, ordenó que tomasen dinero de otras donaciones que hizo al monasterio, en CARRERo SANTAMARía, «Ntra. Sra. de Fresdelval», p. 315; AHN, Clero, Legajo 1.053, doc. 7; AHN, Clero, L. 18.978, ff. 39r y 43v; Serrano Fatigati, «Manriques y Padillas», p. 91; López Mata, Teófilo. El barrio e iglesia de San Esteban. Burgos: Ayuntamiento de Burgos, 1946, pp. 16-17 y La ciudad y castillo, p. 85; RuIz, S. y Álamo, M. Burgos: la ciudad con sus parroquias, conventos, etc. y la diócesis con su historia y obispos, etc. con otros artículos. Extracto del Dictionnaire d'Histoire et de Géographie écclésiastiques, tomo X. Paris: Letourey et Ané, 1938, col. 12491376, col. 1300; Lora Serrano, «La fundación», p. 315; Alonso Ruiz, Begoña y Martínez de Aguirre, 

BENEFACTORÍA Y DEVOCIÓN JERÓNIMA EN LA CASTILLA BAJOMEDIEVAL JUAN A. PRIETO SAYAGUÉS Y DIANA LUCÍA GÓMEZ-CHACÓN

Las galerías del claustro constituyen, en palabras de Carrero, un claro ejemplo de arquitectura gótica retardataria. Están formadas por simples parejas de lancetas apuntadas con hexalóbulos, un esquema conocido en Castilla desde el siglo xirI y que en Fresdelval se recuperó en la tercera década del siglo xv. Solución que Alonso y Martínez de Aguirre han descrito como de "continuidad y ambición limitada». No es casualidad que otras fundaciones ligadas a la reforma religiosa europea del siglo Xv, a las cuales no se les puede acusar de falta de medios materiales -como el claustro de Santa María la Real de Nieva o el monasterio de Santa Clara de Medina de Pomar-, presenten ese aspecto arcaizante, marcado por una aparente escasa ambición técnica que respondería, quizás, a una intencionalidad de sesgo espiritual, que relacionaba sencillez arquitectónica y observancia ${ }^{13}$.

Según señaló Carrero, la construcción de las galerías claustrales provocó evidentes desajustes entre los soportes de las bóvedas del claustro y los accesos a las dependencias (Figura 3$)^{14}$. No se conservan restos de la sacristía medieval, situada entre el transepto

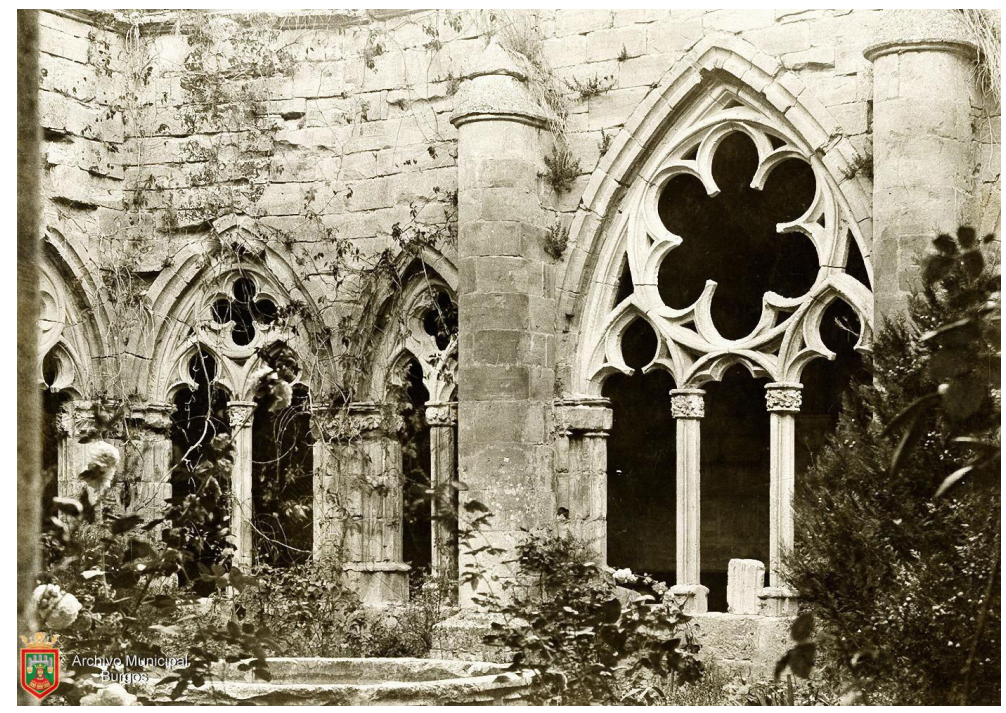

Figura 3. Vista parcial del claustro del Monasterio de Nuestra Señora de Fresdelval en ruinas. Archivo General del Ayuntamiento de Burgos, Colección Gráfica, FC-3587.

Javier. «Arquitectura en la Corona de Castilla en torno a 1412». Artigrama, 2011, vol. 26, p. 121; CARrero Santamaría, «Ntra. Sra. de Fresdelval», pp. 301-302.

13 Carrero Santamaría, «Ntra. Sra. de Fresdelval», p. 308; Alonso Ruiz y Martínez de Aguirre, «Arquitectura», p. 121; Paulino Montero, Elena. El patrocinio arquitectónico de los Velasco (1313-1512): construcción y contexto de un linaje en la Corona de Castilla. Tesis doctoral. Madrid: Universidad Complutense de Madrid, 2015, p. 187; Lucía Gómez-Chacón, Diana. El Monasterio de Santa María la Real de Nieva. Reinas y Predicadores en tiempos de reforma (1392-1445). Segovia: Diputación Provincial de Segovia, 2016, pp. 99-106.

14 Carrero Santamaría, «Ntra. Sra. de Fresdelval», pp. 308-311; Serrano Fatigati, «Monasterio de Fresdelval», pp. 217-222. 
LA FUNDACIÓN Y LAS PRIMERAS DÉCADAS DEL MONASTERIO DE FRESDELVAL. MEMORIA, BENEFACTORÍA Y DEVOCIÓN JERÓNIMA EN LA CASTILLA BAJOMEDIEVAL

JUAN A. PRIETO SAYAGUÉS Y DIANA LUCÍA GÓMEZ-CHACÓN

y la sala capitular, a causa de la ampliación del monasterio llevada a cabo en el siglo Xvi y posterior derrumbe del transepto sur. La sala capitular o capilla de San Jerónimo se concluyó en fecha posterior a la muerte del adelantado. Hacia 1432 la comunidad se vio obligada a solicitar ayuda económica a Pedro López de San Jorge, quien donó 500 florines para acabar la dicha capilla de çerrar y poner vedrieras y otras cosas neçessarias ${ }^{15}$. Solo se conservan los muros que delimitan un espacio cuadrangular que pudo estar cubierto por una bóveda de terceletes e iluminado a través de un rosetón en el muro sur y una ventana de tracería en el lado oriental. Lamentablemente, los escudos sostenidos por ángeles que decoran el guardapolvos del acceso no conservan sus armas.

\section{El sepulcro de Gómez Manrique y Sancha de Rojas}

Gómez Manrique falleció en Córdoba el 3 de junio de 1411, siendo enterrado en la capilla mayor de Fresdelval el 8 de julio. Su esposa murió el 16 de octubre de 1437. En el siglo xvin el sepulcro, colocado en origen frente al altar mayor, fue dividido, al entorpecer el desarrollo de los oficios litúrgicos, quedando la mitad con la imagen yacente del adelantado, colocada en el lado del Evangelio y, la de su esposa, bajo la lápida de Luisa Padilla (Figura 4$)^{16}$.

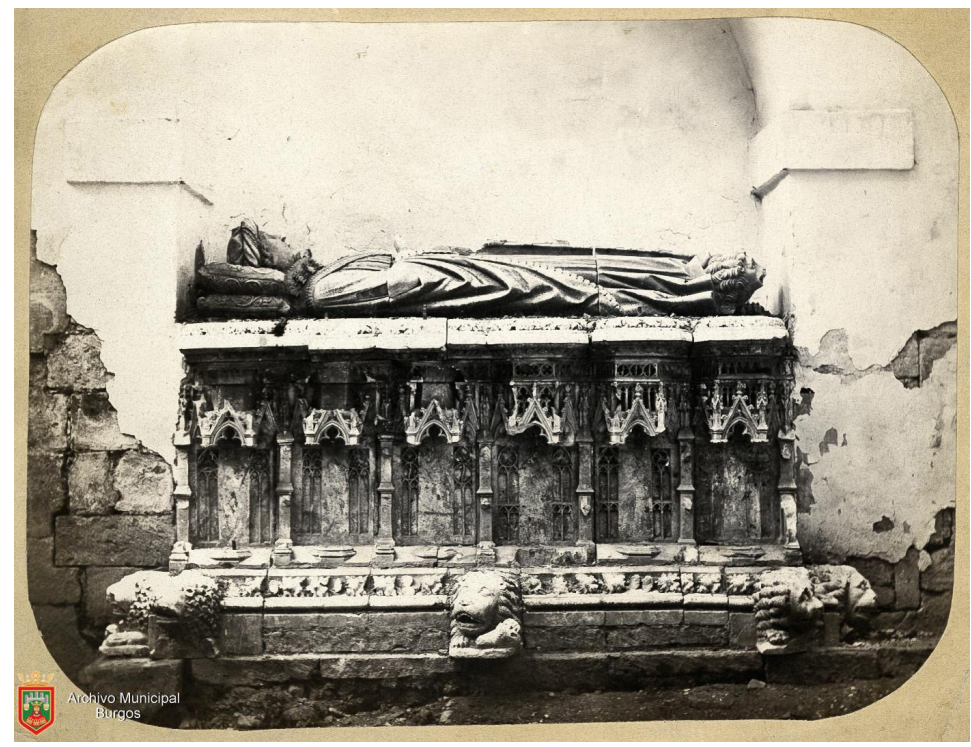

Figura 4. El sepulcro de Gómez Manrique antes de su traslado al Museo de Burgos. Archivo del Ayuntamiento de Burgos. Colección Gráfica, FC-3980.

15 AHN, Clero, L. 18.978, ff. 38r y 41 r; Carrero Santamaría, «Ntra. Sra. de Fresdelval», p. 305.

16 Serrano Fatigati, «Monasterio de Fresdelval», p. 217 y «Manriques y Padillas», p. 94; Gómez BárCENA, «El sepulcro», p. 32; AHN, Legajo 1.053, docs. 3 y 7; RuIz HeRnANDo, Los monasterios, pp. 182-183. 

BENEFACTORÍA Y DEVOCIÓN JERÓNIMA EN LA CASTILLA BAJOMEDIEVAL JUAN A. PRIETO SAYAGUÉS Y DIANA LUCÍA GÓMEZ-CHACÓN

El sepulcro de Gómez Manrique y Sancha de Rojas (Figura 5) consta de un alto zócalo, a modo de basamento, decorado con leones. La peana del sepulcro está dividida en encasamentos, seis en las caras laterales, y, posiblemente, tres en la cabecera y los pies, separados por pilares que rematan en pináculos. Entre pilar y pilar se abren espacios, hoy vacíos, cobijados por doseles con agudos gabletes sobre un arco apuntado trilobulado. Se conservan restos de pedestales que albergarían, en origen, santos o plorantes. Como señaló Gómez Bárcena, estos últimos no son habituales en los sepulcros burgaleses, pero adquirieron una gran importancia en el ámbito borgoñón y en la zona catalano-aragonesa-navarra. Uno de los ejemplos más importantes de esta última región es el sepulcro de Carlos III el Noble en la catedral de Pamplona, obra de Janin Lome, originario de Tournai, y perteneciente a la corriente estilística borgońona, con la que la autora relaciona el sepulcro del adelantando (Figura 6) ${ }^{17}$.

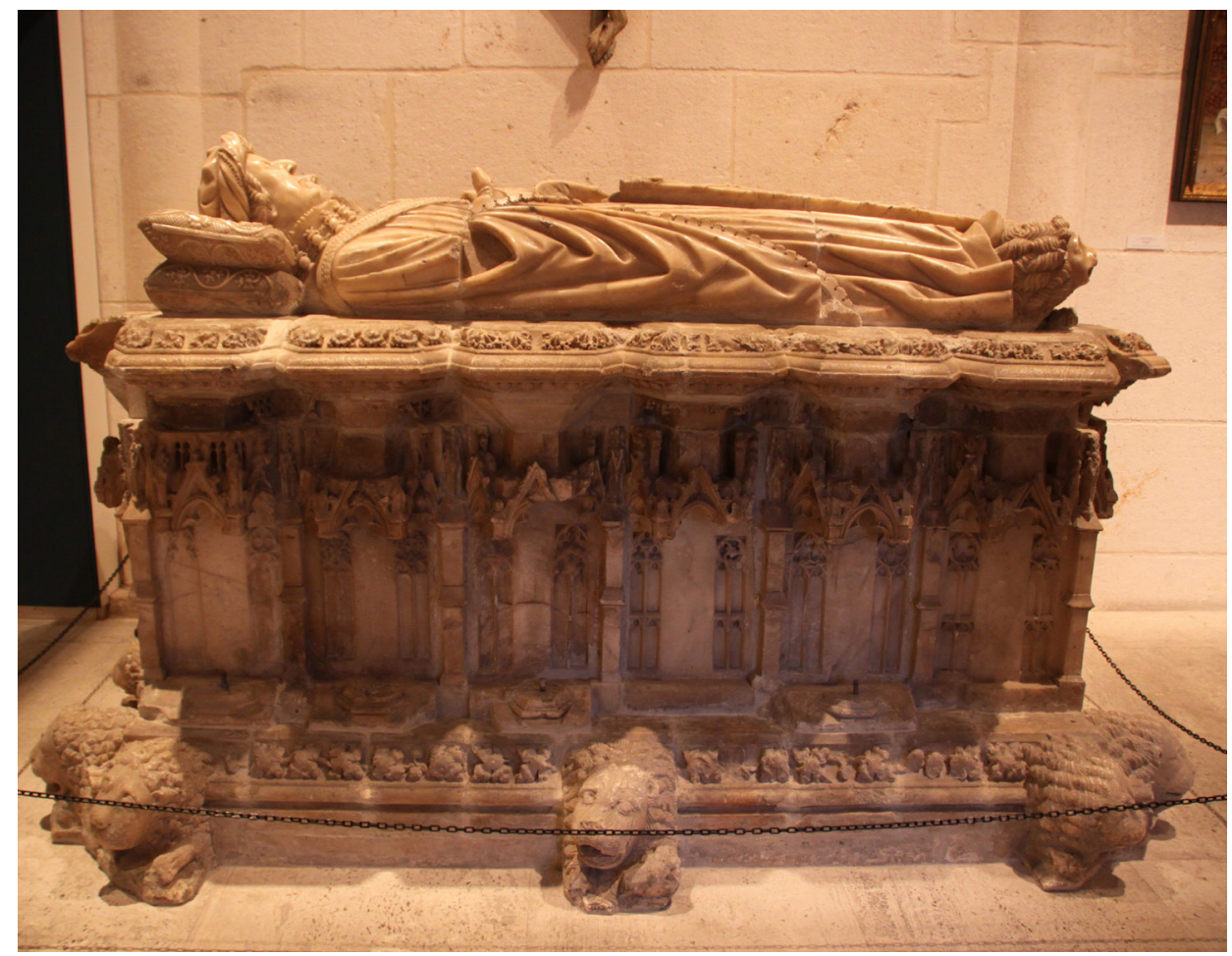

Figura 5. Sepulcro de Gómez Manrique y Sancha de Rojas, c 1410. Museo de Burgos.

17 Gómez Bárcena, «El sepulcro», p. 30; Balaguer, En Burgos, p. 118; Lahoz, Lucía. «La escultura en la corona de Castilla: una polifonía de ecos». Artigrama, 2011, vol. 26, p. 280. 


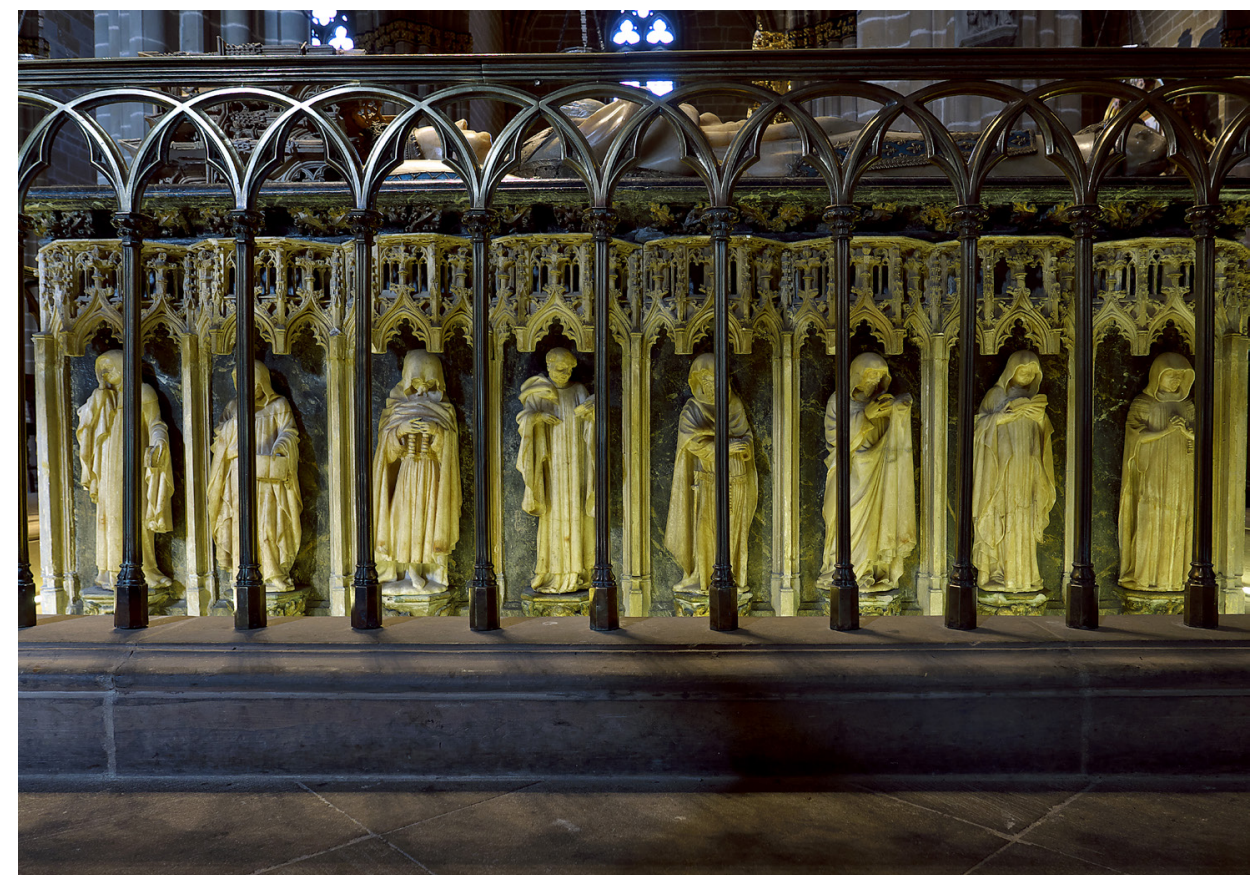

Figura 6. Sepulcro de Carlos III el Noble y de Leonor de Trastámara, 1413-1419. Detalle. Catedral de Pamplona.

Tampoco es habitual en el entorno artístico burgalés la forma quebrada que presentan la parte superior de la peana y el borde de la cama. Las imágenes yacentes de Gómez Manrique y Sancha de Rojas, de 1,90 y 1,82 m de largo, respectivamente, apoyan sus cabezas sobre dobles almohadas. Según la descripción que Fernán Pérez de Guzmán hizo del noble en sus Generaciones y Semblanzas, este era «de buena altura e de fuertes miembros, baço e calvo, el rostro grande, la nariz alta [...] mal ataviado de su persona», información que pone de manifiesto la idealización que presenta la efigie funeraria de Gómez Manrique. Por lo tanto, no se percibe el realismo advertido por investigadores como Wethey ${ }^{18}$.

A pesar de que la toca que luce la imagen yacente del adelantado recuerda al turbante morisco o xásia, se trata, en realidad, de un capirote compuesto de un rollo, una cresta y una beca o chía que cuelga, que Yarza describe como «una especie de falso turbante que estaba de moda a inicios del siglo xv en Francia y que correspondía a miembros de la recién creada orden de caballería del Grifo». A pesar de que en ocasiones se ha dudado

18 Gómez BÁarcena, «El sepulcro», pp. 30, 32 y 34, nota 8; Wethey, Harold Edwin. Gil de Siloé and his school. Cambridge, Mss: Harvard University Press, 1936, p. 58; MARTínez de Aguirre, Javier. «Pride and memory: perceptions of individuality in Iberian sculpture around 1400». Journal of Art Historiography, 2017, vol. 17, p. 15. 

BENEFACTORÍA Y DEVOCIÓN JERÓNIMA EN LA CASTILLA BAJOMEDIEVAL JUAN A. PRIETO SAYAGUÉS Y DIANA LUCÍA GÓMEZ-CHACÓN

sobre la cronología del sepulcro -fechándolo con posterioridad a 1438-, puesto que resulta una obra atípica en el panorama castellano, un análisis detenido permite fecharla, como ya demostró Gómez Bárcena, hacia $1410^{19}$.

Sabemos que entre 1400 y 1410, en el campo de la indumentaria, se mantuvo el estilo iniciado en la última década del siglo xIv, caracterizado, en el ámbito masculino, por los cuellos altos y cerrados, detalle que vemos en la efigie del adelantado (Figura 7). El matrimonio viste hopas y la efigie de la dama lleva encima una mantonina -prenda característica del vestuario femenino castellano de finales del siglo XIv y principios del siglo $\mathrm{XV}-$, resultando de especial interés las bandas que decoran su vestimenta, cuya presencia fue señalada por Carderera. Este autor hace alusión a una noticia recogida en la Historia genealógica de la casa de Lara, según la cual Juan II hizo entrega de la Banda a María Álvarez de Lara y a su hijo e hija. Años antes, Juan I flexibilizó la concesión de la divisa de la

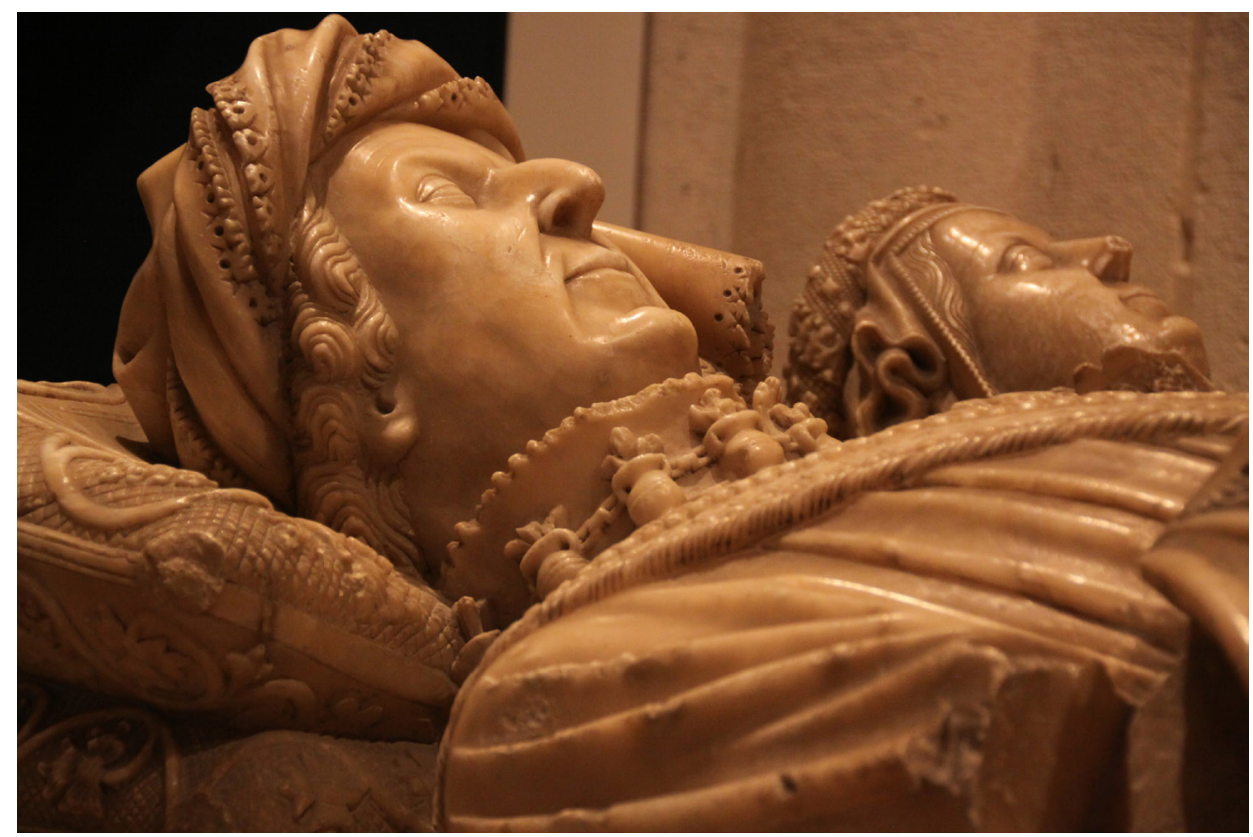

Figura 7. Sepulcro de Gómez Manrique y de Sancha de Rojas, c 1410. Detalle. Museo de Burgos.

19 Bernis Madrazo, Carmen. Indumentaria medieval española. Madrid: Consejo Superior de Investigaciones Científicas, 1956, lámina 47 y p. 43; GiL, Memorias históricas, p. 110; Barrón García, Aurelio A. «El retablo de Torres de Medina y las empresas artísticas de Juan Fernández de Velasco, camarero mayor de Castilla». Goya. Revista de Arte, 2008, vol. 322, p. 27; Gómez BÁrCEnA, «El sepulcro», pp. 30 y 32-34, nota 20; Concejo Díez, M. ${ }^{a}$ Luisa. El arte mudéjar en Burgos y su provincia. Tesis doctoral. Madrid: Universidad Complutense de Madrid, 1999, tomo I, p. 46; Yarza Luaces, La nobleza, pp. 89 y 125-126; LAHOZ, "La escultura», p. 280; Wethey, Gil de Siloé, p. 58; Martínez de Aguirre, «Pride and memory», p. 16; Valero Molina, Joan. "El sepulcre de Berenguer d'Anglesola i els seus referents en l'escultura funerària europea». Annals de l'Institut d'Estudis Gironins, 2004, vol. XLV, pp. 705-706 y 710. 
LA FUNDACIÓN Y LAS PRIMERAS DÉCADAS DEL MONASTERIO DE FRESDELVAL. MEMORIA, BENEFACTORÍA Y DEVOCIÓN JERÓNIMA EN LA CASTILLA BAJOMEDIEVAL

JUAN A. PRIETO SAYAGUÉS Y DIANA LUCÍA GÓMEZ-CHACÓN

Banda al otorgarla a las mujeres de Palencia por su defensa frente al duque de Lancaster, autorizándolas a portarla en sus tocados y ropas (1387). Asimismo, Fernando de Antequera concedió la divisa de la Jarra «a los cavalleros y dueñas de linaje», dato este último que, quizás, podría justificar la presencia de la Banda en las vestiduras de Sancha ${ }^{20}$.

Yarza calificó el sepulcro del noble y su mujer de "obra maestra", cuya existencia «solo se explica por la llegada desde algún lugar del norte de alguien del que desconocemos si fue llamado por el adelantado y su mujer». Gómez Bárcena relaciona el sepulcro del cardenal Berenguer de Anglesola, de Pere Oller, en la catedral de Gerona, con los de Carlos III de Navarra y la reina Leonor, en la de Pamplona, y los de Gómez Manrique y su esposa, hipótesis respaldada por Valero, quien considera el sepulcro del adelantado y su mujer obra de un maestro estrechamente vinculado a Tournai ${ }^{21}$.

El sepulcro de Carlos III el Noble y su esposa se considera la obra cumbre de Lome. A este último y a su taller se atribuyen otras obras conservadas en la catedral de Pamplona como el sepulcro del obispo Sancho Sánchez de Oteiza, el de Leonel de Garro, la puerta del crucero norte y la Virgen de las Buenas Nuevas. El sepulcro real fue realizado entre finales de 1413 y julio de 1419 , y se habría llevado a cabo en dos fases: la primera entre el 10 de octubre y el 16 de junio de 1414, y, la segunda, entre febrero de 1416 y julio de $1419^{22}$.

Lome procedía de los Países Bajos meridionales y se documenta por primera vez en Navarra en agosto de 1411. Junto a él colaboraron Anequin de Sora, Michel de Reims, Johan de Lista (Lille), Vicent Huyart y Johan de Borgoña, interviniendo estos tres últimos solo en la fase inicial. A la segunda fase de ejecución del sepulcro se sumaron Colin de Reims, Johan de la Garnia de Picardía y Johanto de Tolosa ${ }^{23}$.

En base a un análisis formal de los rostros de los veintiocho plorantes que decoran los costados del sepulcro, cubiertos por baldaquinos arquitectónicos trapezoidales, cuyos laterales presentan un diseño similar al del nivel inferior de los doseles regios, apeados en contrafuertes rematados por pináculos, Fernández-Ladreda ha distinguido dos grupos.

20 Bernis Madrazo, Carmen. «El vestido y la moda». En García de la Concha, Víctor (coord.). La cultura del Renacimiento (1480-1580). Madrid: Espasa Calpe, 1999, p. 44 y lámina 128; GómEz BÁRCENA, «El sepulcro», pp. 31 y 32; Carderera y Solano, Valentín. Iconografía española. Colección de retratos, estatuas, mausoleos y demás monumentos inéditos de reyes, reinas, grandes capitanes, escritores, etc. desde el siglo XI hasta el XVII. Madrid: Imprenta de Ramón Campuzano, 1855-1864, tomo I, fol. XLIVv. y nota 1; FERNÁNDEZ DE Córdova, Álvaro. «El emblema de la Banda entre la identidad dinástica y la pugna política en la Castilla bajomedieval (c. 1330-1419)». Emblemata, vol. 20-21, pp. 145 y 154-155.

21 Yarza Luaces, La nobleza, pp. 125-126; Valero Molina, «El sepulcre», pp. 705-706, 710 y 715.

22 Fernández-Ladreda, Clara. «La escultura en Navarra en la primera mitad del siglo xv. Johan Lome y su círculo». Anales de Historia del Arte, 2012, vol. 22, pp. 7-9 y "Escultura. Johan Lome y los talleres coetáneos». En Fernández-Ladreda, Clara (coord.). El arte gótico en Navarra. Pamplona: Gobierno de Navarra, 2015, p. 513; Martínez de Aguirre, Javier, Arte y monarquía en Navarra, 1328-1425. Pamplona: Gobierno de Navarra, Departamento de Educación y Cultura, Institución Príncipe de Viana, 1987, pp. 114 y 320 y «Pride and memory», p. 6.

23 Fernández-Ladreda, «La escultura en Navarra», pp. 9-10, «La escultura en Navarra en tiempos del Compromiso de Caspe». Artigrama, 2011, vol. 26, pp. 203-207 y «Escultura», p. 516; Uranga, José E. «El sepulcro de Mosén Francés». Príncipe de Viana, 1949, vol. 10, n. ${ }^{3} 35-36$, pp. 227-240; Janke, Steven. Jehan Lome y la escultura gótica posterior en Navarra. Pamplona: Diputación foral de Navarra, 1977, pp. 38 y 132-151; Martínez de Aguirre, «Pride», p. 7. 
LA FUNDACIÓN Y LAS PRIMERAS DÉCADAS DEL MONASTERIO DE FRESDELVAL. MEMORIA, BENEFACTORÍA Y DEVOCIÓN JERÓNIMA EN LA CASTILLA BAJOMEDIEVAL JUAN A. PRIETO SAYAGUÉS Y DIANA LUCÍA GÓMEZ-CHACÓN

El primero muestra en los rostros una tendencia a la cuadratura, facciones carnosas, ojos horizontales bien abiertos, ojeras marcadas, barbilla redondeada y presencia de arrugas, especialmente apreciables en el entrecejo, en los pliegues que arrancan de las ternillas nasales y en las comisuras de los labios. Las semejanzas entre estas figuras, la efigie de Carlos III y el yacente del obispo Sánchez de Oteiza hace pensar a la autora que fueron obra de Lome o, al menos, que su intervención fue mayor ${ }^{24}$. El sepulcro de Sánchez de Oteiza se labró entre julio de 1419 y enero de 1422, «etapa en la que se registra un paréntesis en la actividad conocida de Lome». Lome habría intervenido también en el sepulcro de Pere Arnaut de Garro y Juana de Beunza (c 1419-1422) 25 .

Gómez Manrique donó al prior y capellán 29 marcos de plata para confeccionar cuatro cálices y un acetre, y entregó al monasterio los objetos de su capilla, traídos de París. Yarza se planteó la posibilidad de que el adelantado hubiese viajado a Francia, señalando que "en un momento de atonía artística de la Corona de Castilla» el noble "consigue antes de 1411 un escultor de extraordinaria calidad para su sepulcro, sin antecedentes hasta ahora rastreados, ni burgaleses, ni de otro lugar castellano, por lo que hay que suponer que vino de fuera. Pero tampoco se percibe su huella en otras obras». Según Lahoz, el artífice del sepulcro fue «un escultor foráneo introductor hacia 1412 de nuevos aires en la plástica burgalesa, pero sin incidencia en la producción inmediata, por tanto, un caso exótico». Un caso extraño en Castilla, pero no en Navarra, como apuntó Gómez Bárcena ${ }^{26}$.

Al igual que en el de Carlos III y su esposa, la peana del sepulcro del adelantado y su mujer tiene baldaquinos y peanas individuales, rompiendo con el concepto borgoñón de galería claustral y cortejo funerario, detalle que, según Fernández-Ladreda, no conllevaba un desconocimiento por parte del artífice del sepulcro ducal de Dijon, sino una actitud más conservadora por parte de este, ya sea debida a limitaciones técnicas o a los deseos del comitente ${ }^{27}$.

Se supone que Carlos III trajo consigo a Lome al regreso de su tercer y último viaje a Francia (1408-1411). Sin embargo, las semejanzas entre el sepulcro de Gómez Manrique y el de los reyes navarros y el hecho de que la tumba del adelantado estuviese concluida hacia 1410, nos lleva a preguntarnos si Lome o, al menos, uno de sus colaboradores, se encontraba trabajando por aquellas fechas en tierras burgalesas, pasando a Navarra una vez concluida la obra en Fresdelval. Según Janke, Lome habría sido contratado por Carlos III. Aunque resulta una hipótesis atractiva, como apunta Valero, carece de soporte documental, por lo que no descartamos la posibilidad anteriormente expuesta de que

24 FernándeZ-Ladreda, «Escultura», p. 518 y «La escultura en Navarra», pp. 18-19 y 24-28.

25 Balaguer, En Burgos, prólogo, pp. 52, 75 y 125; Serrano Fatigati, "Manriques y Padillas», pp. 91-94 y 217-222; Serrano Fatigati, "Monasterio de Fresdelval», pp. 217-222; Ebro, M. ${ }^{a}$ Cruz. Memorias de una burgalesa, 1885-1931. Burgos: Imprenta de la Diputación Provincial, 1952, pp. 114-115.

26 Yarza LuACES, La nobleza, pp. 88 y 125-126; LAHOz, "La escultura», p. 280; Gómez BÁrCenA, «El sepulcro», p. 33.

27 Fernández-Ladreda, «La escultura en Navarra», p. 21 y «Escultura», p. 520. 
LA FUNDACIÓN Y LAS PRIMERAS DÉCADAS DEL MONASTERIO DE FRESDELVAL. MEMORIA, BENEFACTORÍA Y DEVOCIÓN JERÓNIMA EN LA CASTILLA BAJOMEDIEVAL

JUAN A. PRIETO SAYAGUÉS Y DIANA LUCÍA GÓMEZ-CHACÓN

Lome llegase años antes a la península, por medios distintos, y que el sepulcro de Carlos III no fuese su primer ni único encargo en territorio hispano ${ }^{28}$.

En el testamento de Gómez Manrique se menciona una imagen de Santa Maria en alabastro, que el adelantado ordenó entregar al prior del monasterio, hoy conservada en la Capilla de la Virgen de Villatoro. La Virgen, sedente, sostiene al Niño sentado sobre una de sus rodillas. Carrero, basándose en su indumentaria - un vestido de talle alto y pliegues marcados, ceñido por un cinturón- la fecha a finales del siglo XIV o principios del xv. Esta muestra similitudes formales con el sepulcro de Gómez Manrique y Sancha de Rojas. La fisonomía de la Virgen es similar a la de Sancha, detalle que, como señala el autor, pone en entredicho el carácter retratístico que se ha atribuido a las imágenes yacentes del adelantado y su mujer, además de delatar la misma autoría de ambas obras y corroborar la ejecución del sepulcro en una fecha anterior a $1411^{29}$.

\section{OTROS ESPACIOS FUNERARIOS Y ENTERRAMIENTOS}

Además del sepulcro de los fundadores, en Fresdelval se enterraron otros personajes relevantes en su historia. Si bien se pensaba que la primera inhumación llevada a cabo en la sala capitular, bajo la advocación de san Jerónimo, fue la de Sancha, hija menor del adelantado, fallecida en agosto de 1414 a los 15 ańos de edad, en su testamento expresó su deseo de ser enterrada en la citada capilla do estan enterradas mis hermanas (28/ VI/1414), palabras que pueden aludir a la existencia de más hijas del matrimonio que habrían fallecido en edad temprana. Teresa, la segunda de sus hijas, mandose enterrar en este monesterio junto a la sepultura de su padre a la mano derecha debaxo de una piedra negra llana, a la que se refirió en su testamento como sepultura llana de piedra prieta de Flandes (m. 15/VII/1451). En ese mismo espacio mandó inhumarse Mencía (m. 7/IV/1460) sexta hija de los fundadores y heredera del patronato del monasterio tras la muerte de su madre- junto a su marido, Juan de Padilla, bajo dos laudas negras. La capilla de Santa Ana, situada en el cuerpo de la iglesia, a mano izquierda según se entraba, fue el espacio escogido por otra de las hijas de los fundadores, María, quien anuló su decisión, llegando a amenazar a la comunidad de expulsarla y privarla de todos sus bienes, al enterarse de que había sido enterrada en la capilla la esclava negra de un burgalés ${ }^{30}$.

Tenemos constancia de otros enterramientos en Fresdelval, como los de Alfonso de Ruydobro, hijo de Gonzalo Alfonso de Ruydobro y morador en Quintanilla de Monoçisla, quien donó para ello una tierra en dicho término carrera de Villa Lihierno que heredó de su difunta abuela, Sancha Rodríguez. Fernán Alonso de Sasamón, clérigo bachiller in vitro jure, vecino de Burgos y mayordomo mayor de las Huelgas (m. 20/VIII/1435) se sepultó en medio del crucero, ante las redes del coro en derecho de la sepultura del 707.

28 Fernández-Ladreda, «La escultura en Navarra», p. 22; Valero Molina, «El sepulcre», pp. 706-

29 Carrero Santamaría, «La Virgen», pp. 81-84.

30 Carrero Santamaría, «Ntra. Sra. de Fresdelval», pp. 305-306; AHN, Clero, Legajo 1.053, docs. 1 y 2; AHN, Clero, Libro 18.978, ff. 43r-45r. 
LA FUNDACIÓN Y LAS PRIMERAS DÉCADAS DEL MONASTERIO DE FRESDELVAL. MEMORIA, BENEFACTORÍA Y DEVOCIÓN JERÓNIMA EN LA CASTILLA BAJOMEDIEVAL JUAN A. PRIETO SAYAGUÉS Y DIANA LUCÍA GÓMEZ-CHACÓN

adelantado, delante de la sepultura del escribano Gonzalo García, donde el preste decía el responso por Gómez Manrique cuando acababa la misa, a igual que Juana López (5/V/1439). Juan Gómez, vecino de Obierna, hizo lo propio (7/IX/1439), ordenando sepultarse en el lugar del monasterio que escogiese el prior, al igual que la vecina de Burgos Mari Sánchez, hija de Juan Sánchez de Jaén y mujer de Gonzalo Sánchez de Tártales. Finalmente, el señor de Poza, hijo de Juan Rodríguez de Rojas y esposo de Catalina de Castilla, Diego de Rojas, dispuso su inhumación en la Capilla del Capítulo, en una sepultura llana de azófar de las que traen de Flandes (4/VII/1464) ${ }^{31}$.

\section{LAS DONACIONES Y DOTACIONES DE OFICIOS DE LOS FUNDADORES Y BIENHECHORES}

A lo largo de sus vidas y en los albores de la muerte, Gómez Manrique y su mujer donaron al monasterio tierras, rentas, ganado, carretas, herramientas, ropa de cama, plata, vestimentas, hábitos y ajuar litúrgico. Otras donaciones realizadas por el matrimonio fueron materializadas por sus hijas, quienes entregaron dos pares de casas en la colación de Santiesteban de Burgos, unas donde moraba Sancha de Rojas cuando falleció, otras junto a ellas en la calle entre medias, más viejas, y un solar junto a las primeras, que había donado su madre (2/II/1440). Fray Simón, en nombre de Fresdelval, tomó posesión de los 5.000 maravedís de juro que las hijas del adelantado tenían en Frómista y que, como herederas, dieron al monasterio con licencia de sus maridos, en virtud de la donación hecha por sus difuntos padres; la renta estaba situada en los 20.000 maravedís de juro que estos les dejaron en las rentas y alcabalas de la villa $(30 / \mathrm{I} / 1441)^{32}$.

Gómez Manrique ordenó en su testamento que los religiosos cantasen las misas y treintanarios revelados y cantados que había dotado por su alma y las de su esposa, su padre Pedro Manrique, su tío Juan García Manrique -arzobispo de Santiago-, sus suegros Ruy Díaz de Rojas y María de Guevara y sus descendientes; el contenido de la donación

31 AHN, Clero, Legajo 1.053; AHN, Clero, Libro 18.978; AHN, Clero, Pergaminos, carp. 220, n.o 1; Salazar y Castro, Luis. Pruebas de la historia de la Casa de Lara. Madrid: Imprenta Real, 1694, p. 77; RAH, Salazar y Castro, M-9, f. 390r-v.

32 Gómez Manrique, en su testamento (21/IV/1410) encargó que la plata, ajuar doméstico, imágenes y ricos tejidos que Juan Fernández de Villanuño entregase al prior y capellán, se destinase para ajuar litúrgico del monasterio y le ordenó que les entregase una servilla de 5 marcos y medio de peso; una copa con su sobrecopa de 5 marcos, onzas y una ochava, ambos de plata dorada; un collar de San Francisco de 5 onzas y media de plata que le había dado Ruy; un collar de oro de San Francisco que pesó con el aljófar, 1 marco y 7 onzas; dos bacines de plata de 5 marcos y 5 onzas; una pieza de cendal verde, otro pedazo de cendal bandado de hasta 4 varas; un alba con sus corporales; una imagen de alabastro de la Virgen; una pieza de paño de seda con labores para vestimenta; una caja de cuchillos; 18 varas de fazalejas de Flandes; una alfombra y dos carpetas. Los fundadores dieron bienes muebles y ropas para la sacristía, de las que solo queda constancia de dos capas de brocado, una de carmesí roja con ramos y alcachofas, otra de brocado leonado bien andada y un ornamento viejo de carmesí colorado con brocado entretejido. Los bienes del matrimonio que quedaron para el monasterio fueron 35.000 maravedís de juro situados en el peso y hierro herraje, las casas, pisón, molino, era y 370 fanegas en Celada. Las hijas del adelantado eran María, mujer de Gómez de Benavides; Teresa, viuda del repostero mayor del rey, Juan de Avendańo; Juana, mujer del seńor de Montealegre, Pedro Manuel; Elvira, esposa de Juan Rodríguez de Rojas; y Mencía, de Juan de Padilla, en AHN, Clero, Legajo 1.053; AHN, Clero, Libro 18.978; AHN, Clero, Pergaminos, carp. 220, n. ${ }^{4}$. 
LA FUNDACIÓN Y LAS PRIMERAS DÉCADAS DEL MONASTERIO DE FRESDELVAL. MEMORIA, BENEFACTORÍA Y DEVOCIÓN JERÓNIMA EN LA CASTILLA BAJOMEDIEVAL

JUAN A. PRIETO SAYAGUÉS Y DIANA LUCÍA GÓMEZ-CHACÓN

aparecía en el documento de dotación del monasterio, igual que las misas diarias que tenían que decir por el matrimonio. Mandó todo el pan que alcanzó de Rui Sánchez y lo que le debía dicho ańo para que dijeran 300 misas. Al margen de lo anterior, la comunidad decía diariamente por el matrimonio dos responsos y varias misas, diferentes en función del día de la semana, y, anualmente, cuatro aniversarios cantados ${ }^{33}$.

Sus hijas hicieron otras donaciones a título individual. Teresa donó una heredad que heredó de sus padres en Hurones, consistente en una torre antigua de argamasa con sus casas alrededor y cinco pedazos de tierras y huertos de unas 114 fanegas de sembradura; 2.000 maravedís de juro de los 9.000 que tenía en Santoyo y que le correspondió por herencia, estando ya viuda de Juan de Avendaño, puesto que los bienes del monasterio eran insuficientes (1440 y 1441); unos candelabros de plata blancos de 14 marcos de peso, una custodia sobredorada de más de 13 marcos en que llevaban el Sacramento el día del Corpus y varios ornamentos y sábanas, muchas de ellas de lienzo de Vizcaya. Sancha, en su testamento donó al monasterio 1.000 florines de oro por las almas de su padre, sus abuelos -el adelantado Pedro Manrique y Ruy Díaz de Rojas-, la suya y la Virgen para reparo y para adquirir posesiones para el monasterio y 10.000 maravedís para comprar ornamentos (1414). En su codicilo, confirmó y amplió las donaciones de su testamento. Ordenó que llevasen sobre sus andas dos paños de oro y que después se destinasen para hacer casullas para decir misa. Según el libro del monasterio cumplio muy poco desto su madre doña Sancha de Rojas porque tuvo necesidad para casar las otras hijas. La sexta hija, Mencía, y su marido Juan de Padilla, donaron ornamentos y lienzos ${ }^{34}$.

33 Se decían por el matrimonio diariamente al alba una misa rezada de la Virgen y los domingos y fiestas dobles se podía decir la misa de la fiesta, debiendo pronunciarse en ella la oración Deus bene largitor por los bienhechores; los lunes se decía misa de réquiem cantada, si no fuera fiesta doble o de guardar, caso en el que debía de decirse la de réquiem y los viernes misa de réquiem rezada con oración por los bienhechores. Los dos responsos que decían diariamente tenían lugar, uno después de los maitines, si no era fiesta doble o de guardar, y el otro después de las vísperas, diciéndose en ellos oración por los bienhechores. Los cuatro aniversarios consistían en una vigilia de tres responsos por la tarde, tras lo que se bajaba sobre sus sepulturas con cruz, capa y agua bendita, y al día siguiente se decía misa de réquiem cantada con su responso, participando toda o la mayor parte de la comunidad; los días en que tenían lugar eran el 3 de junio - día en que falleció el adelantado-, 9 de julio - día de su sepultura-, 16 de octubre - fecha del fallecimiento de Sancha de Rojas- y el 4 de febrero -ordenado por sus hijas-, en AHN, Clero, Libro 18.978.

34 Teresa hizo la donación en la capilla de San Jerónimo (16/IV/1440), al igual que la de la heredad de Hurones (24/IX/1441). El rey asentó los 5.000 maravedís de juro que tenían las hijas del adelantado en las alcabalas de Frómista y los 2.000 que tenía Teresa en Santoyo (8/VI/1440 y 17/XII/1441). Con el tiempo, los 7.000 maravedís se situaron en las alcabalas del hierro de Burgos. Teresa donó en su testamento 120.000 maravedís para que rogasen por su alma, sus familiares y cargos, para que los invirtiesen en cosas que rentasen para el monasterio para mantenimiento de la comunidad y para el culto divino; tres marcos y medio de plata para un cáliz y unas ampollas y para hacerlas. Su hijo Pedro de Avendaño, ballestero mayor, y los que tuvo su hija Sancha con Martín Ruiz de Artiaga, como tutor y curador de sus hijos con su cuńado, Pedro de Avendaño, traspasaron a Fresdelval 7.000 maravedís de juro en Santoyo -que había comprado el padre de Teresa a mosén Juan de Ría, vasallo del rey y camarero del rey de Francia, con otros 30.000 que tenía este último de los reyes de Castilla, con facultad para enajenarlos-, para cumplir la manda que había hecho Teresa, concertándose con el prior y comunidad por intercesión de Juan de Padilla y Mencía, hermana de Teresa (30/XI/1451), año en que falleció esta última; el 3 de diciembre tuvo lugar el traspaso de Pedro de Avendaño. Arrendaron a censo perpetuo la heredad y casa fuerte de Hurones que esta dama donó al concejo del lugar por 76 fanegas 
LA FUNDACIÓN Y LAS PRIMERAS DÉCADAS DEL MONASTERIO DE FRESDELVAL. MEMORIA, BENEFACTORÍA Y DEVOCIÓN JERÓNIMA EN LA CASTILLA BAJOMEDIEVAL JUAN A. PRIETO SAYAGUÉS Y DIANA LUCÍA GÓMEZ-CHACÓN

$\mathrm{Al}$ igual que los fundadores, otros miembros de ambos linajes -Manrique y Rojasdotaron oficios litúrgicos de carácter puntual y perpetuo, como el seńor de Poza, Diego de Rojas; el de Requena, Gome Díaz de Rojas y la I condesa de Haro, Beatriz Manrique. Los fundados por sus hijas -Sancha (1414), María (1441), Teresa y Mencía (1460)- eran en su mayoría encargos por su alma, pero también se acordaron de sus padres, esposos y tíos. Se constata otra donación de Leonor Carrillo, señora de Cervera y esposa del camarero mayor Fernando de Velasco, la cual se entiende por la relación entre los Manrique y los Velasco, al igual que ocurrió con la I condesa de Haro ${ }^{35}$.

Entre los bienhechores del monasterio se documentan oficiales y criados del adelantado y varios religiosos, quienes también dotaron misas y aniversarios. Juan Martínez Calabaza, mayordomo mayor de Gómez Manrique, y su mujer, vecinos de Frómista, contribuyeron con las obras de Fresdelval donando 2 florines de censo perpetuo situados en una viña que tenían en Frómista, junto al monasterio benedictino. Mari Sánchez, hija de Juan Sánchez de Jaén y mujer de Gonzalo Sánchez Tártales, vecina de Burgos, ordenó que, si hubiese algún heredero del difunto Juan Hurtado, criado y escribano del adelantado, le pagasen 100 maravedís que le debía y, si no tuviese heredero, que se dotasen misas por él en el monasterio (27/VI/1441). Entre los religiosos que hicieron donaciones a la ermita y posterior monasterio y encargaron oficios se encuentran el capellán de la ermita, García Fernández (1407), y los clérigos de Ubierna, Juan Fernández (1410 y 1414), de

de pan, mitad trigo, mitad cebada (12/VII/1467), en AHN, Clero, Libro 18.978; AGS, EMR, MyP, Leg. 3, n. ${ }^{\circ}$ 86; AHN, Clero, Pergaminos, carp. 220, n. ${ }^{\text {os }} 5$ y 14; AHN, Clero, Legajo 1.053.

35 En su testamento (28/VI/1414), Sancha mandó celebrar el día de su entierro 30 misas reveladas; una misa diaria por su alma durante el primer ańo en la capilla donde se enterrase, que debía celebrar un religioso del monasterio e ir después sobre su fosa; decir el día de san Bartolomé, anualmente, una memoria y una misa cantada de réquiem en el altar de la capilla donde se enterraba y salir sobre su fosa; 30 misas reveladas. María encargó 400 misas por su alma dejando 1.500 maravedís y otros 150.000 para que rogasen a Dios y dijesen semanalmente tres misas rezadas por las almas de sus padres y su tío, el arzobispo de Santiago; en su codicilo (30/IX/1441) mandó pagar los 150.000 maravedís cuatro o cinco años después de su fallecimiento. Teresa hizo varias donaciones y los religiosos pidieron en un capítulo general que se le dijese una misa rezada semanalmente y un aniversario cantado el 15 de julio. Mencía ordenó a sus albaceas dar al monasterio renta -entregaron 12.000 maravedís de juro- de sus bienes para dotar una capellanía de cuatro misas semanales y dos aniversarios por ella y su marido, uno el 7 de abril -fecha del fallecimiento de la dama en 1460- y el otro el 8 de agosto. Su hijo, Pero López de Padilla, adelantado mayor de Castilla, dio los 12.000 maravedís de juro que mandaron dar los cabezaleros de su madre asentados en esta manera: en las alcabalas de Burgos, 5.000; en las alcabalas y tercias de Hurones, 3.750; en las alcabalas y tercias de Villaynda, 1.000; en las tercias de Saldañuela, 1.100; y en las alcabalas y tercias de Coxobar, 1.150 (25/V/1480). Diego de Rojas, señor de Poza, en su testamento (4/VII/1464) mandó 2.000 maravedís de juro porque rogasen por su alma y la de Catalina, su mujer, quien en sus últimas voluntades mandó otros 1.000 maravedís de juro; en su codicilo donó 10.000 maravedís de juro y, si les fuesen contradichos por el rey, ordenó que le dieran 1.000 maravedís de capellanía perpetua para que rogasen por su alma y la de su mujer. El señor de Requena, en su codicilo (2/III/1475) entregó 1.500 maravedís porque rogasen por las almas de sus difuntos que ende estan y por la suya. La I condesa de Haro, en su testamento (1471) mandó 3.000 maravedís porque ayan memorial del alma del conde my señor e mya, ya que los jerónimos no podían salir del monasterio para hacerle las exequias. Leonor Carrillo donó 500 maravedís para que, cuando se enterasen de su fallecimiento, dijesen una vigilia por la noche y, al día siguiente, misa cantada de réquiem y que rogasen por su alma, en AHN, Clero, Legajo 1.053; AHN, Clero, Libro 16.807 y 18.978; AHNo, Frías, C. 598, D. $38-39$ y C. 1716, D. 6 y Fernán Núnez, C. 2059, D. 32; RAH, Salazar y Castro, M-6, f. 41 y M-9, f. 390r-v. 
LA FUNDACIÓN Y LAS PRIMERAS DÉCADAS DEL MONASTERIO DE FRESDELVAL. MEMORIA, BENEFACTORÍA Y DEVOCIÓN JERÓNIMA EN LA CASTILLA BAJOMEDIEVAL

JUAN A. PRIETO SAYAGUÉS Y DIANA LUCÍA GÓMEZ-CHACÓN

San Miguel de Vivar, Ruy Pérez (1413), y el referido Fernán Alonso de Sasamón (m. 20 de agosto de 1435). Juan Fernayz de Castrillo, cura de la capilla de Santiago, y Ruy González de Villalierno, donaron heredades en Villalierno; a cambio de ello, los religiosos ordenaron decirles un aniversario cantado anual. Las donaciones consistieron en casas y heredades de cereal, sin cargo alguno. Se constatan otros donantes de Ubierna como Juan Gómez, hombre de armas ${ }^{36}$.

Otro núcleo importante de donantes y dotadores de oficios en el monasterio, en sus estadios iniciales, estuvo integrado por vecinos de Burgos con grados académicos, miembros del concejo como regidores, tesoreros, personajes pudientes, otros de extracción desconocida y personas del entorno de la villa ${ }^{37}$.

36 Por Juan Martínez Calabaza se decía un aniversario anual cantado el 2 de octubre. El capellán compró unas casas para el templo al clérigo de Santa Olalla, Fernando González (1407), y otras a Juan Delgado, vecino de Quintanilla -donde estaban ambas-. Juan Fernández donó una heredad en Ubierna y su término, compuesta de varias tierras, reteniéndolas durante su vida a cambio de entregar al monasterio 12 fanegas de pan -mitad trigo y mitad cebada-, situados en dicho lugar y, después de fallecer, informaría en su testamento quién tendría el cargo de continuar pagando dichas fanegas; si no lo hicieran, autorizaba al cenobio a tomarlas; si en algún momento los provisores del monasterio no quisiesen tenerlas, ordenó que lo arrendasen en el concejo de Ubierna a quien más diese por ellas, prohibiendo enajenarlas (21/VI/1410); hizo una donación y los frailes ordenaron que le dijesen anualmente un aniversario el día de su fallecimiento (20/XI/1414). Juan de Ortega, clérigo de Ubierna y sobrino del anterior, cuando falleció su tío entregó las tierras al monasterio (9/ XI/1415). Ruy Pérez donó una tierra de cereal que tenía en término de Soto Palacios a do dicen la Quintana y 10 maravedís anuales de lo que rentaban unas casas pajizas que tenía en Vivar, reteniendo estas durante sus vidas y ordenando que después de fallecer quedasen para el pariente más próximo y que continuase pagando la renta; el motivo de la donación era tener parte en los bienes y sacrificios que se hacían en el monasterio y porque rogasen por su alma y la de sus difuntos, permitiendo enajenarla (6/III/1413). Fernán Alonso de Sasamón dotó misas y treintanarios; en su testamento mandó dividir su hacienda en tres partes correspondiéndole una al monasterio para que rogasen por su alma y otra para que dijeran misas y treintanarios por su alma y por quienes tenía cargo; aunque dejó la tercera parte de sus bienes sin cargo, los religiosos le decían aniversario cantado cada 20 de julio. Juan Fernández, cura de la iglesia de San Juan de Obierna, en su testamento mandó que la heredad que tributó a Fresdelval, la tuviera su criado Pedro Fernández y sus nietos, Pedrico y Juanico, y que pagasen el tributo de 12 fanegas de pan a Fresdelval, ellos y sus descendientes, el día de Santa María de septiembre y ordenó al monasterio que no se la quitasen mientras pagasen el tributo (13/XI/1440). Juan Gómez, en su testamento mandó que todo lo que compró en uno con su mujer se diese al monasterio, excepto lo que dejó por escrito en el documento y la mitad de las casas que mandó a su hermana Mencía (7/ IX/1439); el contenido de lo anterior eran unas medias casas y 26 pedazos de tierras y 50 fanegas de sembradura en Ubierna, otros bienes muebles y un caballo. Juan Fernayz de Castrillo y Ruy González de Villalierno dieron heredades en Villalierno y los religiosos les decían un aniversario anual cantado el 15 de diciembre, en Revuelta Somalo, Los jerónimos, pp. 273-274; AHN, Clero, Pergaminos, carp. 217, n. ${ }^{\circ} 19$ y carp. 218 , n. ${ }^{\text {os }}$ 5 y 17; AHN, Clero, Libro 18.978; AHN, Clero, Legajo 1.053.

37 Fernando Martínez, bachiller en leyes y regidor de Burgos, en su testamento le donó la heredad que dejó su padre, el también regidor Francisco Martínez, en Celada o en Hurones que estaba junto a otra del monasterio y mandó decir misas de réquiem -cinco a reverencia de san Jerónimo y del Nacimiento de la Virgen; tres a la Concepción; dos a la Anunciación y el mismo número a la Virgen; una al ángel Gabriel, el Espíritu Santo, la Trinidad y la Pasión de Jesucristo; una a honra de cada uno de los siguientes santos: Miguel, Nicolás, Domingo, Julián, Leonardo, Francisco, Sebastián, Anastasia y Catalina-; mandó dar 500 maravedís de pitanza por todas ellas; ordenó decir por el alma de su padre, Francisco Martínez, cinco misas de réquiem por 100 maravedís y una carga de trigo (21/X/1422). La comunidad decía anualmente un aniversario el día de su fallecimiento (20/IX/1422) por él y por sus padres. Se confirmó la donación de la heredad de Celada del Camino por su madre y herederos que tenían parte en la misma (10/V/1423); entre sus hijos estaba Juan 
LA FUNDACIÓN Y LAS PRIMERAS DÉCADAS DEL MONASTERIO DE FRESDELVAL. MEMORIA, BENEFACTORÍA Y DEVOCIÓN JERÓNIMA EN LA CASTILLA BAJOMEDIEVAL JUAN A. PRIETO SAYAGUÉS Y DIANA LUCÍA GÓMEZ-CHACÓN

A cambio de las donaciones, el monasterio y su comunidad ofrecieron una serie de servicios a los fundadores y bienhechores. Por lo que respecta al monasterio como lugar físico, este fue empleado como lugar de redacción de testamentos, archivo familiar y «banco de depósitos». En el complejo de Fresdelval, incluido el palacio de Sancha de Rojas, redactaron sus testamentos miembros de la familia de los fundadores como la hija del adelantado, Sancha, estando enferma (28/VI/1414) y el señor de Poza, Diego de Rojas (4/VII/1464); habitantes de Burgos o su entorno como Mari Sánchez y Alfonso de Ruydobro (27/VI/1441) y de lugares más lejanos como la señora de Mejorada, Mencía García de Toledo (29/VI/1397). En cuanto a la función del cenobio como archivo, en su fondo documental hay una confirmación de Enrique IV (5/VII/1456) de un documento de Juan II de los 20.000 maravedís que el consejero real, Pedro Manuel, tenía situados en las alcabalas de la carniceria e aver de peso de Burgos, para que pasaran a su mujer Juana Manrique (3/XI/1440), a lo que accedió el rey en 1442. Diego de Rojas, mandó 500 maravedís, depositados en Fresdelval, para el matrimonio de cada una de sus hijas, María y Juana; en el caso de que alguna tomase el hábito, ordenó que solo recibiesen 100 maravedís cada una, pasando el dinero restante a su otra hija, Elvira ${ }^{38}$.

En cuanto al componente humano, los religiosos que integraban la comunidad desempeñaron diferentes cometidos a favor de sus bienhechores como testigos en la redacción de testamentos, albaceas, consejeros de estos últimos para el reparto de las mandas pías, árbitros en conflictos familiares y depositarios de dinero que tenían que entregar o invertir según las órdenes del personaje en cuestión ${ }^{39}$.

Martínez, alcalde del rey en Burgos, y otra de las hijas, Teresa, mujer de Simón Pérez, regidor de la ciudad. Se decía anualmente un aniversario el 10 de mayo por el tesorero Garci Rodríguez de Santa Cruz, vecino de Burgos. Alfonso González de Soria y su mujer, Catalina Ximénez, personas principales de Burgos, donaron 500 doblas (c 1440-1450) y, cuando ella murió, 25.000 maravedís; dieron ornamentos y sábanas para los altares. Pedro López de San Jorge y Aldonza Rodríguez, su mujer, vecinos de Burgos, ayudaron a acabar la capilla de San Jerónimo (c 1432) y les decían un aniversario cantado anual el 16 de junio. A Domingo Fernández, Mari Fernández, su mujer, y Pedro Fernández de Cortes, del que el escriba desconoce más datos, se les decía un aniversario el 27 de enero. Pedro González de Medina, vecino de Burgos, en su testamento donó 5 maravedís (25/XI/1413). Sancho Fernández, de Villaverde del Monte, y su mujer, Juana Fernández, vecinos de Burgos, donaron todos sus bienes muebles y raíces para la tabla de la comunidad; ya habían hecho testamento y lo habían dejado como heredero; hicieron esta donación para que fuese más firme (12/II/1418). Mari Sánchez, hija de Juan Sánchez de Jaén y mujer de Gonzalo Sánchez Tártales, en su testamento mandó que del remanente de sus bienes muebles y raíces, que tenía en Quintanilla de Monoçisla y en sus términos, fuese para Fresdelval, para que rogasen por su alma y la de sus difuntos (27/VI/1441); donaron para su reparo y mantenimiento todas las casas, corrales, herrenes, muradales, solares, palmietos y tierras de cereal, vińas, prados, pastos, ejidos, árboles, huertas, aguas y otros bienes raíces que tenían en dicho lugar permitiendo enajenarlos, por las misas que decían por ellos (15/VI/1445), en AHN, Clero, Pergaminos, carp. 204, n.o 15; carp. 205, n. o 5; carp. 218 , n. ${ }^{\text {s }} 17$ y 18; carp. 220, n. ${ }^{\text {os }} 1$ y 10; AHN, Clero, Libro 18.978; AHN, Clero, Legajo 1.053.

38 Alfonso de Ruydobro, hijo de Gonzalo Alfonso de Ruydobro, morador en Quintanilla de Monoçisla, redactó su testamento en el dicho monesterio de santa Maria de Fresdelval en los palacios de doña Sancha de Rojas (25/X/1422), en AHN, Clero, Pergaminos, carp. 221, n. ${ }^{\circ}$ 1; AHN, Clero, Legajo 1.053; RAH, Salazar y Castro, M-9, f. 390r-v y M-36, ff. 173v a 176v; Salazar y Castro, Pruebas, p. 77.

39 En el testamento de Sancha, hija de Gómez Manrique, estaba presente como testigo Juan de Guadalupe, seguramente religioso de Fresdelval (28/VI/1414). El adelantado estableció como cabezaleros al vicario de Guadalupe, al que ordenó que fuera prior de Fresdelval, y al clérigo y capellán del monasterio, Garci Fernández (21/IV/1410). Fernán Alonso de Sasamón, dejó por albaceas a García de las Hormazas, prior de 
LA FUNDACIÓN Y LAS PRIMERAS DÉCADAS DEL MONASTERIO DE FRESDELVAL. MEMORIA, BENEFACTORÍA Y DEVOCIÓN JERÓNIMA EN LA CASTILLA BAJOMEDIEVAL

JUAN A. PRIETO SAYAGUÉS Y DIANA LUCÍA GÓMEZ-CHACÓN

\section{Conclusiones}

A pesar de los avatares que sufrió el monasterio desde su saqueo por las tropas francesas y su posterior desamortización, los restos conservados, tanto in situ como musealizados, son más que suficientes para poner de manifiesto su relevancia histórico-artística. La revisión de la documentación que ha llegado hasta nosotros relativa al periodo correspondiente al patronato de Gómez Manrique y sus familiares directos demuestra que se trata de una obra concebida como un espacio memorial, panteón de sus fundadores y descendientes, y que, posiblemente, responda a los preceptos estéticos de aparente sencillez técnica y aspecto retardatorio propios de la espiritualidad reformadora que, por aquel entonces, comenzaba a extenderse por Europa.

La capilla mayor fue el lugar reservado para cobijar los cuerpos de Gómez Manrique y su esposa, en un sepulcro doble que se conserva en el Museo de Burgos y que muchos consideran un ejemplo singular en el panorama peninsular del siglo xv, de ahí que algunos investigadores retrasasen su cronología. Sin embargo, en este trabajo retomamos la hipótesis de Gómez Bárcena, secundada por otros autores, y situamos su ejecución hacia 1410, relacionando esta con el taller de Lome, quien pudo llegar a Castilla en fechas previas a su intervención en las obras encargadas por Carlos III en Navarra.

Además de las donaciones, sepulturas y encargo de oficios litúrgicos por parte de la familia del adelantado y su esposa, también lo hicieron sus criados y oficiales, religiosos, personas de poblaciones cercanas y vecinos de Burgos. Muchos de estos oficios eran perpetuos, al igual que las dotaciones de los mismos, lo que garantizaba al monasterio ingresos periódicos, pese al fallecimiento de sus patrones y benefactores. A cambio de dicha benefactoría, el monasterio y su comunidad ofreció una serie de servicios socioeconómicos a sus bienhechores como lugar de redacción de testamentos, archivo familiar y «banco de depósitos», y sus religiosos fueron testigos en la redacción de testamentos, albaceas, árbitros en conflictos familiares y depositarios de dinero de dichos personajes.

En definitiva, la fundación, construcción y dotación del monasterio de Fresdelval constituye un buen ejemplo del creciente protagonismo que adquirieron las fundaciones

Fresdelval, y a Juan de Olmos, profeso del mismo (8/VIII/1435). Leonor Carrillo, señora de Cervera, nombró albacea a Juan de Santllorente, monje de Fresdelval (1452). Uno de los cabezaleros del señor de Poza fue el prior de Fresdelval (1464). Alfonso de Ruydobro mandó que sus albaceas diesen 500 maravedís por su alma con consejo del prior y donde este creyese que sería mejor para la salvación de su alma (25/X/1422). En la escritura que hicieron las hijas de Sancha de Rojas fueron árbitros el maestro dominico Martín de Santa María, prior de Santa María de Rojas, y Juan de Cereceda, de Fresdelval. Los herederos lo aceptaron, pero al poco tiempo, reclamaron y no aceptaron el acuerdo (3/III/1440). Gómez Manrique, en su testamento dejó dinero y bienes, encargando vender estos últimos al prior y al capellán Garci Fernández, para que de su importe se pagaran las querellas que tuviera pendientes y, lo que sobrase, que se invirtiese en las obras del monasterio, claustro, refectorio, dormitorio y moradas (21/IV/1410). El adelantado mandó que Ruy Sánchez de Velasco diera el pan que ordenó el testador y 1.773 florines de oro del cuño de Aragón, 87 coronas y 2 doblas moriscas, que dejó en Córdoba en guarda de Juan Fernández de Villanuño, al prior y al capellán, para cumplir y pagar las querellas que tuviera en Castilla, Galicia y en otras partes; si no llegara con lo anterior, ordenó al prior y al capellán tomar más dinero de los 50.000 maravedís que mandó para pagar las querellas, en AHN, Clero, Legajo 1.053; AHN, Clero, Libro 18.978; AHNo, Fernán Núńez, C. 2059, D. 32; Salazar y Castro, Pruebas, p. 77 e Historia, p. 420; RAH, Salazar y Castro, M-9, f. 390r-v; Revuelta Somalo, Los jerónimos, p. 272. 
LA FUNDACIÓN Y LAS PRIMERAS DÉCADAS DEL MONASTERIO DE FRESDELVAL. MEMORIA, BENEFACTORÍA Y DEVOCIÓN JERÓNIMA EN LA CASTILLA BAJOMEDIEVAL JUAN A. PRIETO SAYAGUÉS Y DIANA LUCÍA GÓMEZ-CHACÓN

jerónimas en tierras castellanas en la Baja Edad Media, y del apoyo y protección que recibieron estas por parte no solo de los monarcas, sino también, y muy especialmente, de los oficiales de la corte, a los que pertenecieron tanto los fundadores de la Orden de San Jerónimo, como el propio Gómez Manrique. A la memoria de este último quedó ligado el monasterio de Fresdelval durante sus primeros ańos de andadura, un legado que fue heredado más tarde por los Padilla.

\section{Fuentes INÉDitAS}

AGS, EMR, MyP, Leg. 3, n.o 86.

AHN, Clero, L. 18.978.

AHN, Clero, Legajo 1.053.

AHN, Clero, Libro 16.807

AHN, Clero, Pergaminos, carp. 204, n. ${ }^{\circ} 15$; carp. 205, n. ${ }^{\circ}$; carp. 217, n. ${ }^{\text {os }} 13$ y 19; carp. 218 , n. ${ }^{\text {ss }} 1,5,10,17$ y 18 ; carp. 220, n. $^{\text {os }} 1,4,5,10$ y $14 ;$ carp. 221, n. ${ }^{\circ} 1$.

AHNo, Fernán Núńez, C. 2059, D. 32; Frías, C. 598, D. 38-39 y C. 1716, D. 6.

RAH, Salazar y Castro, M-6 y M-9.

\section{REFERENCIAS BIBLIOGRÁFICAS}

Alonso Ruiz, Begoña y Martínez de Aguirre, Javier. «Arquitectura en la Corona de Castilla en torno a 1412». Artigrama, 2011, vol. 26, pp. 103-148.

Araus Ballesteros, Luis y Villanueva Zubizarreta, Olatz. "Espacios, identidades y relaciones de los musulmanes de la ciudad de Burgos durante su minoría mudéjar». En Echevarría Arsuaga, Ana y Fábregas García, Adela (coords.). De la alquería a la aljama. Madrid: UNED, 2016, pp. 167-194.

Balaguer, Víctor. En Burgos. Recuerdos de esta ciudad insigne. Madrid: El Progreso Editorial, 1895.

Barrón García, Aurelio A. «El retablo de Torres de Medina y las empresas artísticas de Juan Fernández de Velasco, camarero mayor de Castilla». Goya. Revista de Arte, 2008, vol. 322, pp. 23-46.

Beceiro Pita, Isabel. «La nobleza y las órdenes mendicantes en Castilla (1350-1530)». En Beceiro PIta, Isabel (coord.). Poder, piedad y devoción. Castilla y su entorno. Siglos XII-XV. Madrid: Sílex, 2014, pp. 319-358.

Bernis Madrazo, Carmen. «El vestido y la moda». En García de la Concha, Víctor (coord.). La cultura del Renacimiento (1480-1580). Madrid: Espasa Calpe, 1999, pp. 153-174.

Bernis Madrazo, Carmen. Indumentaria medieval española. Madrid: Consejo Superior de Investigaciones Científicas, 1956.

Cañas Gálvez, Francisco de P. «Devoción mariana y poder regio: las visitas reales al monasterio de Guadalupe durante los siglos XIv y xv (ca. 1330-1472)». Hispania Sacra, 2012, vol. LXIV, n. ${ }^{\circ} 130$, pp. $427-447$.

Cañas Gálvez, Francisco de P. El itinerario de la corte de Juan II de Castilla (1418-1454). Madrid: Sílex, 2007. 
LA FUNDACIÓN Y LAS PRIMERAS DÉCADAS DEL MONASTERIO DE FRESDELVAL. MEMORIA, BENEFACTORÍA Y DEVOCIÓN JERÓNIMA EN LA CASTILLA BAJOMEDIEVAL

JUAN A. PRIETO SAYAGUÉS Y DIANA LUCÍA GÓMEZ-CHACÓN

Carderera y Solano, Valentín. Iconografia española. Colección de retratos, estatuas, mausoleos y demás monumentos inéditos de reyes, reinas, grandes capitanes, escritores, etc. desde el siglo XI hasta el XVII. Madrid: Imprenta de Ramón Campuzano, 1855-1864, tomo I.

Carrero Santamaría, Eduardo. «La Virgen del adelantado mayor de Castilla don Gómez Manrique, originaria del monasterio jerónimo de Nuestra Señora de Fresdelval». Archivo Español de Arte, 1994, n. ${ }^{\circ}$ 265, pp. 79-84.

Carrero Santamaría, Eduardo. «Ntra. Sra. de Fresdelval y sus nobles fundadores. Una fábrica monástica condicionada a su patronazgo». En Campos y Fernández de Sevilla, Francisco J. (coord.). La Orden de San Jerónimo y sus monasterios. Actas del Simposium (I). San Lorenzo del Escorial: Ediciones Escurialenses, 1999, pp. 295-316.

Castro, Manuel de. El Real Monasterio de Santa Clara de Palencia y los Enríquez, Almirantes de Castilla. Palencia: Diputación Provincial de Palencia, 1982.

Concejo Díez, M. ${ }^{a}$ Luisa. El arte mudéjar en Burgos y su provincia. Tesis doctoral. Madrid: Universidad Complutense de Madrid, 1999.

Ebro, M. ${ }^{a}$ Cruz. Memorias de una burgalesa, 1885-1931. Burgos: Imprenta de la Diputación Provincial, 1952.

Fernández de Córdova, Álvaro. «El emblema de la Banda entre la identidad dinástica y la pugna política en la Castilla bajomedieval (c. 1330-1419)». Emblemata, vol. 20-21, pp. 121-170.

Fernández-Ladreda, Clara. «Escultura. Johan Lome y los talleres coetáneos». En FernándezLadreda, Clara (coord.). El arte gótico en Navarra. Pamplona: Gobierno de Navarra, 2015, pp. 513-551.

Fernández-Ladreda, Clara. «La escultura en Navarra en la primera mitad del siglo xv. Johan Lome y su círculo". Anales de Historia del Arte. 2012, vol. 22, pp. 7-37.

Fernández-Ladreda, Clara. «La escultura en Navarra en tiempos del Compromiso de Caspe». Artigrama, 2011, vol. 26, pp. 185-242.

GIL, Isidro. Memorias históricas de Burgos y su provincia. Burgos: Imprenta de Segundo Fournier, 1913.

Gómez Bárcena, M.a Jesús. «El sepulcro de Gómez Manrique y Sancha de Rojas. Conservado en el Museo Arqueológico de Burgos». Reales Sitios. Revista del Patrimonio Nacional, 1985, vol. 83, pp. 29-36.

González de Fauve, M. ${ }^{a}$ Estela. La Orden Premonstratense en España. El Monasterio de Santa María de Aguilar de Campoo (siglos XI-XV). Tomo I: Texto. Aguilar de Campoo: Centro de Estudios del Románico, 1991.

Janke, Steven. Jehan Lome y la escultura gótica posterior en Navarra. Pamplona: Diputación Foral de Navarra, 1977.

Ladero Quesada, Miguel Á. «Mecenazgo real y nobiliario en monasterios españoles: los jerónimos (siglos xv y XvI)». Príncipe de Viana. Homenaje a José María Lacarra, 1986, Anejo 3-vol. XLVII, pp. 409-440.

LaHoz, Lucía. «La escultura en la corona de Castilla: una polifonía de ecos». Artigrama, 2011, vol. 26, pp. 243-286.

López Mata, Teófilo. El barrio e iglesia de San Esteban. Burgos: Ayuntamiento de Burgos, 1946.

López Mata, Teófilo. La ciudad y castillo de Burgos. Burgos: Ayuntamiento de Burgos, 1920.

Lora Serrano, Gloria. "La fundación del monasterio de San Vicente de Plasencia. La tumba del poder». En Córdoba de la Llave, Ricardo; Pino García, José Luis del y Cabrera SÁnchez, Margarita (coords.). Estudios en homenaje al profesor Emilio Cabrera. Córdoba: Universidad de Córdoba, 2015, pp. 307-328. 
LA FUNDACIÓN Y LAS PRIMERAS DÉCADAS DEL MONASTERIO DE FRESDELVAL. MEMORIA, BENEFACTORÍA Y DEVOCIÓN JERÓNIMA EN LA CASTILLA BAJOMEDIEVAL JUAN A. PRIETO SAYAGUÉS Y DIANA LUCÍA GÓMEZ-CHACÓN

Lucía Gómez-Chacón, Diana. El Monasterio de Santa María la Real de Nieva. Reinas y Predicadores en tiempos de reforma (1392-1445). Segovia: Diputación Provincial de Segovia, 2016.

Martínez de Aguirre, Javier, Arte y monarquía en Navarra, 1328-1425. Pamplona: Gobierno de Navarra, Departamento de Educación y Cultura, Institución Príncipe de Viana, 1987.

Martínez De Aguirre, Javier. «Pride and memory: perceptions of individuality in Iberian sculpture around 1400». Journal of Art Historiography, 2017, vol. 17, pp. 1-25.

Martínez Díez, Gonzalo. Nacimiento y muerte de un monasterio burgalés. Santa María de Fresdelval. Burgos: Imprenta de la Diputación, 1996.

Montero Tejada, Rosa M. ${ }^{a}$. Nobleza y sociedad en Castilla. El linaje Manrique (siglos XIV-XVI). Madrid: Caja Madrid, 1996.

Paulino Montero, Elena. El patrocinio arquitectónico de los Velasco (1313-1512): construcción y contexto de un linaje en la Corona de Castilla, tesis doctoral. Madrid: Universidad Complutense de Madrid, 2015.

Prieto Sayagués, Juan A. «La orden jerónima: un siglo de servicio y bajo la protección de la monarquía y los oficiales de la corte Trastámara (1373-1474)». En CaÑas Gálvez, Francisco de P. y Nieto Soria, José M. (coords.). Casa y Corte. Ámbitos de poder en los reinos hispánicos durante la Baja Edad Media (1230-1516). Madrid: La Ergástula, 2019, pp. 97-122.

Revuelta Somalo, Josemaría. Los jerónimos. Guadalajara: Institución Provincial de Cultura Marqués de Santillana, 1982.

Rodríguez-Picavea Matilla, Enrique. «Nobleza y sociedad en la Castilla bajomedieval. El linaje Padilla en los siglos XIv-XV». Studia Historica. Historia Medieval, 2015, vol. 33, pp. 121-153.

Ruiz, S. y Álamo, M. Burgos: la ciudad con sus parroquias, conventos, etc. y la diócesis con su historia y obispos, etc. con otros articulos. Extracto del Dictionnaire d'Histoire et de Géographie écclésiastiques, tomo X. Paris: Letourey et Ané, 1938.

Ruiz de Loizaga, Saturnino. Documentación medieval de la diócesis de Burgos en el Archivo Vaticano (siglos XIV y XV). Roma: el augtor, 2003.

Ruiz Hernando, José Antonio. Los monasterios jerónimos españoles. Segovia: Caja Segovia, 1997.

Salazar y Castro, Luis. Historia genealógica de la Casa de Lara, tomo I. Madrid: Imprenta Real, 1696.

Salazar y Castro, Luis. Pruebas de la historia de la Casa de Lara. Madrid: Imprenta Real, 1694.

Serrano Fatigati, Enrique. "Manriques y Padillas. Brevísma historia de Fresdelval». La Ilustración Española y Americana, 1894, vol. XXX, pp. 91-94.

Serrano Fatigati, Enrique. «Monasterio de Fresdelval. Galerías bajas del claustro procesional, ventanas del templo». Boletín de la Sociedad Española de Excursiones, 1902, vol. 117, pp. 217-222

Sigüenza, José de. Historia de la Orden de San Jerónimo. Valladolid: Junta de Castilla y León, 2000, tomo I.

Uranga, José E. «El sepulcro de Mosén Francés». Príncipe de Viana. 1949, vol. 10, n. ${ }^{\circ}$ 35-36, pp. 227-240.

Valero Molina, Joan. «El sepulcre de Berenguer d'Anglesola i els seus referents en l'escultura funerària europea». Annals de l'Institut d'Estudis Gironins, 2004, vol. XLV, pp. 687-731.

Wethey, H. Gil de Siloé and his school. Cambridge, Mss: Harvard University Press, 1936.

YARZA LuACES, Joaquín. La nobleza ante el rey. Los grandes linajes castellanos y el arte en el siglo XV. Madrid: El Viso, 2003. 